\title{
Establishing the contribution of lawn mowing to atmospheric aerosol levels in American suburbs
}

\author{
R. M. Harvey, J. Zahardis, and G. A. Petrucci \\ Department of Chemistry, University of Vermont, 82 University Place, Burlington, VT, USA \\ Correspondence to: G. A. Petrucci (giuseppe.petrucci@uvm.edu) \\ Received: 20 August 2013 - Published in Atmos. Chem. Phys. Discuss.: 16 September 2013 \\ Revised: 2 December 2013 - Accepted: 6 December 2013 - Published: 23 January 2014
}

\begin{abstract}
Green leaf volatiles (GLVs) are a class of woundinduced volatile organic compounds emitted by several plant species. Turf grasses emit a complex profile of GLVs upon mowing, as evidenced by the "freshly cut grass" smell, some of which are readily oxidized in the atmosphere to contribute to secondary organic aerosol (SOA). The contribution of lawn-mowing-induced SOA production may be especially impactful at the urban-suburban interface, where urban hubs provide a source of anthropogenic oxidants and SOA while suburban neighborhoods have the potential to emit large quantities of reactive, mow-induced GLVs. This interface provides a unique opportunity to study aerosol formation in a multicomponent system and at a regionally relevant scale. Freshly cut grass was collected from a study site in Essex Junction, Vermont, and was placed inside a $775 \mathrm{~L}$ Teflon experimental chamber. Thermal desorption gas chromatography-mass spectrometry (TD-GC/MS) was used to characterize the emitted GLV profile. Ozone was introduced to the experimental chamber and TD-GC/MS was used to monitor the consumption of these GLVs and the subsequent evolution of gas-phase products, while a scanning mobility particle sizer was used to continuously measure aerosol size distributions and mass loadings as a result of grass clipping ozonolysis.

Freshly cut grass was found to emit a complex mixture of GLVs, dominated by cis-3-hexenyl acetate (CHA) and cis-3-hexenol (HXL), which were released at an initial rate of $1.8( \pm 0.5) \mu \mathrm{g}$ and $0.07( \pm 0.03) \mu \mathrm{g}$ per square meter of lawn mowed with each mowing. Chamber studies using pure standards of CHA and HXL were found to have aerosol yields of $1.2( \pm 1.1) \%$ and $3.3( \pm 3.1) \%$, respectively. Using these aerosol yields and the emission rate of CHA and HXL by grass, SOA evolution by ozonolysis of grass clip-
\end{abstract}

pings was predicted. However, the measured SOA mass produced from the ozonolysis of grass clippings exceeded the predicted amount, by upwards of $\sim 150 \%$. The ozonolysis of a mixture of CHA and HXL representative of environmental mixing ratios also failed to accurately model the SOA mass produced by grass clippings. The disparity between measured SOA mass and the predicted SOA mass suggests that grass clippings contain other SOA precursors in addition to CHA and HXL.

Aerial photographs and geospatial analysis were used to determine the area of turfgrass coverage in a suburban neighborhood, which was then used along with measured SOA production as a function of grass mowed to determine that lawn mowing has the potential to contribute $47 \mu \mathrm{g}$ SOA per $\mathrm{m}^{-2}$ of lawn to the atmosphere per mowing event by ozonolysis, which cannot be modeled solely by the ozonolysis of CHA, HXL or a representative mixture of the two.

\section{Introduction}

Volatile organic compounds (VOCs) are emitted by both biogenic (BVOCs) and anthropogenic (AVOCs) sources and play an important role in the chemistry of the atmosphere. The photooxidation of VOCs can lead to the formation of ozone, with which other VOCs can react (along with other atmospheric oxidants) to produce secondary organic aerosol (SOA) (Hallquist et al., 2009; Kroll and Seinfeld, 2008). Organic aerosols, including SOA, are a major component of fine aerosols and influence climate through direct and indirect effects, although there is an expressed high degree of uncertainty about the magnitude of these effects (Kanakidou et al., 2005; Solomon et al., 2007). SOA also impacts local 
weather patterns and has been associated with deleterious impacts on human health (Miller-Schulze et al., 2011; Diaz et al., 2011). Currently, there remains significant uncertainty in our understanding of the environmental impact of SOA, owing to a still-limited knowledge of its sources, composition, properties, and the mechanisms that lead to its formation and ageing (Hamilton et al., 2009; Carlton et al., 2009; Shilling et al., 2013). Identifying the sources, interactions and reactivity of VOCs is integral to understanding their impact on the formation of SOA and consequently on regional air quality and climate patterns.

Though our understanding of the mechanisms that lead to SOA formation has improved, significant gaps exist in our understanding of SOA formation and ageing, namely our understanding of systems with competing reactive pathways. Several recent studies have stressed the potential importance of interactions between AVOCs, BVOCs and oxidants in SOA formation and ageing, and yet these interactions remain largely uncharacterized (Emanuelsson et al., 2013; Glasius et al., 2011; Spracklen et al., 2011; Hoyle et al., 2011; Shilling et al., 2013). Of special interest to our group is SOA production and ageing at the interface of urban and suburban/rural landscapes. This interface offers the unique opportunity to study atmospherically relevant mixtures of anthropogenic and biogenic VOCs and SOA, as will be discussed.

Characterized by a "freshly mowed lawn" smell, the cutting of turfgrass enhances emission of a complex mixture of $\mathrm{C}_{5}$ and $\mathrm{C}_{6}$ BVOCs, along with other low molecular weight oxygenated BVOCs (Kirstine et al., 1998; Brilli et al., 2011; Karl et al., 2005; Ormeno et al., 2010; Hatanaka, 1993; Brilli et al., 2012; Kirstine and Galbally, 2004; Jardine et al., 2012; de Gouw et al., 1999). Together these BVOCs are termed green leaf volatiles (GLVs) (Karl et al., 2001). The most documented GLVs include the $\mathrm{C}_{6}$ compounds cis-3-hexenal, cis3-hexenol (HXL), cis-3-hexenyl acetate (CHA), and trans2-hexenal. More recently, $\mathrm{C}_{5}$ compounds (cis-2-penten-1-ol and 1-penten-3-ol) have also been identified in the woundinduced emissions of plants (Jardine et al., 2012; Karl et al., 2001; Orlando et al., 2001). Not only do these compounds have interesting roles in plant protection and plantplant/plant-animal communication, GLVs also actively take part in atmospheric chemistry (Brilli et al., 2012; Pinto et al., 2007; Hartikainen et al., 2012).

Though individual VOCs differ greatly in their reactivity and consequently their SOA-forming potential, many grass GLVs contain unsaturated double bonds, which are readily oxidized by ozone, hydroxyl radicals and nitrate radicals, providing important potential pathways to the generation of photochemical smog and SOA (Kirstine and Galbally, 2004; Aschmann et al., 1997; Orlando et al., 2001; Hamilton et al., 2009; O'Dwyer et al., 2010; Reisen et al., 2003; Joutsensaari et al., 2005). Brilli et al. (2012) estimate that grassland ecosystems emit up to $130 \mathrm{mg} \mathrm{C} \mathrm{m}^{-2}$ of GLVs annually. Several other studies have reported GLV emission rates on the same order of magnitude for mowed grasses (de Gouw et al., 1999; Olofsson et al., 2003; Kirstine et al., 1998). Lawn coverage in the US has been estimated at 10-16 million ha, which corresponds to a total of $\sim 13-21 \mathrm{Gg} \mathrm{C} \mathrm{yr}^{-1}$ of GLVs emitted by lawns in the US alone (Robbins and Birkenholtz, 2003). Omitting methanol and other low molecular weight GLVs, which account for $\sim 70 \%$ of total GLV emissions and are not readily oxidized in the atmosphere, reactive lawn GLV emissions can be estimated at between 3.9 and $6.3 \mathrm{Gg} \mathrm{C}$ annually. In comparison, annual nonmethane VOCs in North America are estimated at $84 \mathrm{Tg} \mathrm{C}$ (Guenther et al., 2000; Brilli et al., 2012; Kirstine and Galbally, 2004; Kirstine, 2002).

The role reactive GLVs play in global SOA levels, however, is not straightforward. Reports of GLV aerosol yields are varied. CHA is reported to have $8.5-24 \%$ aerosol yield from ozonolysis and less than $1 \%$ aerosol yield from photooxidation, while HXL has been reported to have $9.6 \%$ and $3.1 \%$ aerosol yield from ozonolysis and photooxidation, respectively (O'Dwyer et al., 2010; Hamilton et al., 2009; Hamilton et al., 2008). Based on GLV emission rates and SOA yield efficiencies, lawns in the US alone therefore have the potential to contribute $\sim 0.32-1.5 \mathrm{GgC}$ of SOA to the atmosphere annually. Hamilton et al. (2009) estimated that photooxidation of HXL and CHA contribute as much as 1$5 \mathrm{Tg} \mathrm{C} \mathrm{yr}^{-1}$ of SOA to global emissions, which current mod-

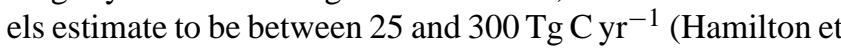
al., 2009; Cahill et al., 2006; Hallquist et al., 2009; Solomon et al., 2007b). Photooxidation of these two GLVs alone could contribute a significant fraction of global SOA. The ozonolysis of GLVs, however, having greater aerosol yields than photooxidation, is likely to be an additional, significant SOA source to the atmosphere with important contributions to climate forcing and air quality at the airshed level.

Hamilton et al. (2009) established the importance of GLV oxidation to global SOA using single-component systems, with one oxidant being introduced to each GLV separately. We extend this work by representing the multi-component system experienced in the environment, especially at the urban-suburban interface. At this interface, traffic and industry located in urban hubs provide a source of anthropogenic oxidants and ASOA, while suburban neighborhoods, with their sprawling monocultural lawns and recreational fields, have the potential to emit large quantities of mow-induced GLVs and BSOA. This scenario provides a unique opportunity to study aerosol formation in a multi-component system and at a regionally relevant scale (Nemitz et al., 2009; Karl et al., 2001; de Gouw et al., 1999; Gulden et al., 2007; Lefohn et al., 2010; Guenther et al., 2012; Steinbrecher et al., 2000). Since grass mowing typically occurs on hot sunny days in a regionally, seasonally and sometimes temporally coordinated fashion, emission of reactive GLVs is expected to occur in large-scale bursts. Simultaneously, tropospheric ozone is often present at elevated concentrations on hot sunny days (Steinbrecher et al., 2000). In urban and suburban environments, GLV bursts into oxidizing atmospheric conditions 
therefore provide an opportunity for concerted bursts of SOA into an airshed. The interface between urban and suburban landscapes provides the opportunity to study SOA formation in a multi-component system at a small spatial and temporal scale, where ASOA can exceed BSOA and where processes leading to SOA formation could be different from those in largely forested regions (Emanuelsson et al., 2013; Fushimi et al., 2011; Steinbrecher et al., 2000; Starn et al., 1998; Aiken et al., 2009).

Although the GLV emission profile of several grass and clover species has been characterized (Watkins et al., 2006; Olofsson et al., 2003; Kirstine et al., 1998; Karl et al., 2001; de Gouw et al., 1999; Brilli et al., 2011, 2012; Kirstine and Galbally, 2004; Kirstine, 2002) and the SOA yields of several individual GLVs have been estimated (Hamilton et al., 2009; Aschmann et al., 1997; O'Dwyer et al., 2010; Joutsensaari et al., 2005), to the best of our knowledge there is no reported work on GLV mixtures with respect to their aerosol yields. In this work, a holistic approach to understanding GLV oxidation and SOA evolution has been used to characterize the contribution of lawn mowing to local SOA levels. Thermal desorption gas chromatography-mass spectrometry (TD-GC/MS) was used to characterize the VOC profile of mowed grass. TD-GC/MS was also used to monitor the consumption of GLVs upon ozonolysis and the subsequent evolution of gas-phase products, while aerosol size distributions and mass loadings were continuously measured using a scanning mobility particle sizer.

We show that the mow-induced GLV emission profile from turfgrass in a suburban neighborhood in Vermont, USA, is dominated by CHA and HXL, which readily undergo oxidation by ozone to form SOA. Aerosol yields were determined for standards of CHA and HXL individually and used to predict SOA evolution for simple, atmospherically relevant mixtures of the two GLVs and for grass clippings collected from the field. An apparent disparity between predicted and measured SOA production, along with the volatile product profile of each chemical system, are discussed herein, highlighting the need to understand more fully the dynamic chemical interactions posed at the urban-suburban interface.

\section{Experimental}

Cis-3-hexenyl acetate (>98\%) and cis-3-hexenol (99\%) were purchased from Sigma Aldrich and were used without further purification. Dry, zero air was produced by passing compressed air sequentially through silica, activated carbon and high-efficiency particulate absoprtion (HEPA) filters. This zero air was also used to generate ozone using a commercially available corona discharge ozone generator (OLSOA/DLS OzoneLab). Ozone concentrations were monitored with an American Ecotech Serinus $\mathrm{O}_{3}$ Monitor (model E020010).
All experiments were performed in a Teflon chamber with a volume of $775 \mathrm{~L}$ at ambient temperature $\left(\sim 23^{\circ} \mathrm{C}\right)$ and atmospheric pressure. Between experiments, the chamber was passivated with $\mathrm{O}_{3}(1-2 \mathrm{ppm})$ and flushed with zero air to attain background aerosol mass loadings below $0.1 \mu \mathrm{g} \mathrm{m}^{-3}$.

Air samples were collected from the reaction chamber onto Air Toxics glass sorption tubes (Perkin Elmer $\mathrm{N} 9307008$ ) that had been previously conditioned at $310^{\circ} \mathrm{C}$ for $20 \mathrm{~min}$ and stored with Swagelok caps. Air was drawn through the sorption tubes using a personal sampler pump (SKC Airchek Sampler, model 224-44XR) at a constant rate of approximately $100 \mathrm{ml} \mathrm{min}^{-1}$ (actual flow rate monitored by a F\&J Specialty Products mini calibrator, model MC$500 \mathrm{cc}$ ) for a known duration of time, allowing the total volume of air sampled to be determined. Typical sample volumes ranged between $0.6 \mathrm{~L}$ and $3.6 \mathrm{~L}$. Rather than diluting with clean air to account for volume loss during sampling, the chamber was allowed to collapse slightly throughout an experiment. Particle filters and ozone scrubbers were not used because some have been shown to retain ozonolysis products (Uchiyama et al., 2012; Helmig, 1997).

Air samples were then transferred from the sorbent tubes by thermal two-step desorption (TurboMatrix TD 350, Perkin Elmer) to a gas chromatograph (Clarus 600, Perkin Elmer) equipped with a mass spectrometer (Clarus $600 \mathrm{~T}$, Perkin Elmer) detector. Prior to desorption, an internal standard of fluorobenzene (AirLiquide) was injected by the Turbomatrix TD directly onto the sorption tubes. During the first step of desorption, the sorbent tubes were heated to $330^{\circ} \mathrm{C}$ for $8 \mathrm{~min}$ to desorb and cryo-focus GLVs onto an Air Monitoring trap (Perkin Elmer, P/N M041-3628) trap held at $-10^{\circ} \mathrm{C}$. The trap was then heated at a rate of $40^{\circ} \mathrm{Cs}^{-1}$ to a final temperature of $310^{\circ} \mathrm{C}$, where it was held for $8 \mathrm{~min}$. The GLVs were transferred to a GC analytical column (Stabilwax $30 \mathrm{~m}, 0.32 \mathrm{~mm}$ i.d., Restek) via a heated transfer line $\left(250^{\circ} \mathrm{C}\right)$. The $\mathrm{GC}$ oven was programmed as follows: held at $35^{\circ} \mathrm{C}$ for $4 \mathrm{~min}$, increasing $10^{\circ} \mathrm{C} \mathrm{min}^{-1}$ to a final temperature of $220^{\circ} \mathrm{C}$. The total run time per sample was $22.5 \mathrm{~min}$. The head pressure of the helium carrier gas was $1.8 \mathrm{psi}$, which resulted in a flow rate of $1.52 \mathrm{ml} \mathrm{min}^{-1}$. Electron impact ionization $(70 \mathrm{eV})$ was used and masses were scanned from 15 to $300 \mathrm{~m} / z$. Chromatographic peaks were identified by comparison of retention times to those of known standards and by spectral matching with the NIST 2005 mass spectral library. Compounds were quantified on area basis using single ion monitoring. Detection limits were found by $\mathrm{LOD}=s_{\mathrm{y}} \cdot t_{\text {crit }} \mathrm{m}^{-1}$, where $s_{\mathrm{y}}$ and $\mathrm{m}$ are the error in the $y$ intercept and slope of the calibration curve, respectively, and $t_{\text {crit }}$ was taken at $95 \%$ confidence level. The detection limits for CHA, HXL and propanal were $0.096 \mu \mathrm{g}, 0.058 \mu \mathrm{g}$ and $0.052 \mu \mathrm{g}$, respectively. Depending on the volume of air sampled, these masses correspond to ppb-level concentrations

Aerosol particle number and mass size distributions, as well as total aerosol mass loadings (assuming an average particle density of $1.2 \mathrm{~g} \mathrm{~cm}^{-3}$ ), were measured continuously 
with a scanning mobility particle sizer (SMPS, model SMPS 3080, TSI Inc., Shoreview, MN).

The vapor pressure of several organic ozonolysis products was estimated using structure-based estimators courtesy of the Dortmund Data Bank found in the online database by Clegg et al. (2008). Estimates were made at $298 \mathrm{~K}$ and are reported as an average of three estimates determined using methods described by Moller et al. (2008), Myrdal and Yalkowsky (1997), Nannoolal et al. (2008), Nannoolal et al. (2004) and Stein and Brown (1994).

\subsection{Grass experiments}

The grass collection site chosen was located in a residential neighborhood in Essex Junction, VT (44.487653, -73.09365), approximately 10 miles east of Burlington, VT (Fig. 1). A geospatial analysis of the study site was performed using ArcGIS 9.0 software. Aerial photographs taken in 2004 were obtained from the Vermont Center for Geographic Information. The resolution of these photos was sufficient to visually identify residential turfgrass; ArcGIS software was used to quantify the area of turfgrass (36 acres) along with the total site area (131 acres).

A section of representative turfgrass comprised predominantly of genera Festuca, Lolium and Poa was mowed using a commercially available, residential lawn mower. Clippings were collected and transported in sealed paper bags to the University of Vermont, Burlington, VT, for analysis. Total time elapsed between mowing and sampling in Teflon chamber was between 60 and $90 \mathrm{~min}$. Samples were collected from nine mowing events between September and November of 2012 and one event in May of 2013.

In grass "clipping" experiments, approximately $0.5 \mathrm{~kg}$ of grass clippings (wet weight) were placed directly inside the experimental chamber, which was then filled with zero air. Approximately $800 \mathrm{ppb}$ ozone was injected directly into the chamber over the course of $\sim 60 \mathrm{~s}$. Grass clipping experiments were designed to represent environmentally relevant conditions, where ozone was allowed to interact with volatile species in the gas phase along with any reactive species contained within or on the blades of grass themselves. In "headspace" experiments, approximately 150 grams of grass clippings (wet weight) were placed in a $0.4 \mathrm{~L}$ conical flask. Zero air was flushed through the conical flask for $\sim 20 \mathrm{~min}$ into the reaction chamber, carrying the GLVs with it. Ozone was injected in the same manner as above. Headspace experiments represented a simplified version of the chemical system of interest, where only the volatile species emitted by cut grass were oxidized by ozone. In general, initial CHA and HXL concentrations were greater in headspace experiments than in clipping experiments. This difference is likely due to experimental design; grass clippings were allowed to equilibrate in the experimental chamber for 20-30 min before ozone was injected while grass headspace was allowed to build up in the paper sampling bag for up to $60 \mathrm{~min}$ be-

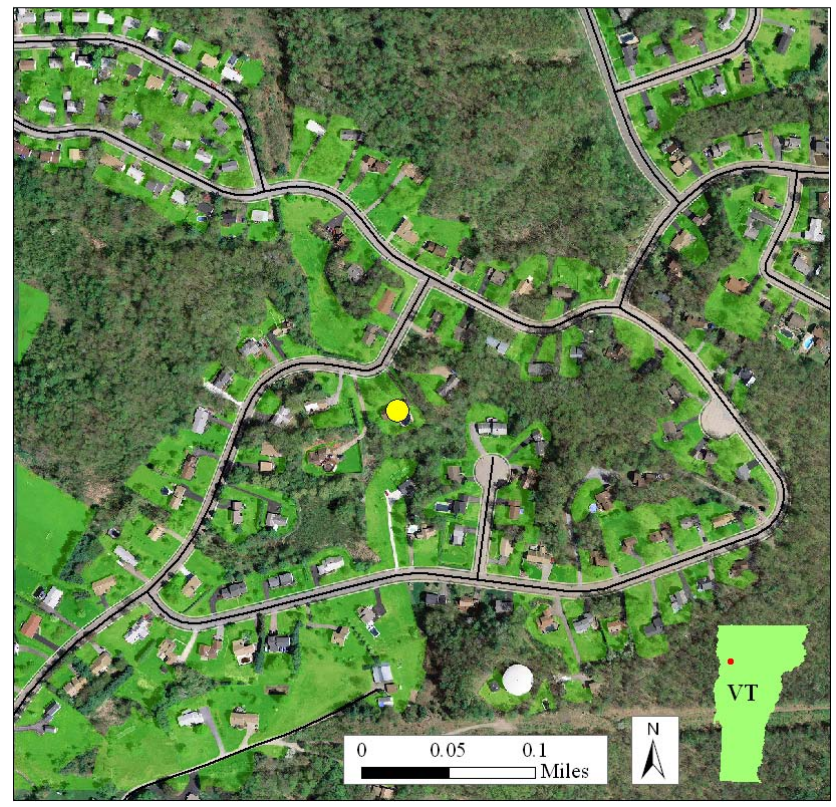

Fig. 1. Turfgrass (light green) in a suburban neighborhood in Essex, VT, comprises $28 \%$ of the total land cover (131 acres), the mowing of which releases a complex profile of unsaturated GLVs, which upon ozonolysis have the potential to contribute to atmospheric SOA. The study site $(44.487653,-73.09365)$ denoted by yellow circle.

fore being flushed into the chamber. Grass clippings, however, continuously emitted GLVs (Fig. S1).

\subsection{GLV standard experiments}

GLV standard experiments were designed to further simplify headspace experiments and were used to determine whether SOA produced as the result of grass ozonolysis could be modeled by a single GLV or a two-component mixture of GLVs. Standards of CHA or HXL were introduced to the experimental chamber by evaporation via injection into a 3neck flask over a warm water bath. After injection, zero air was flushed through the flask and into the reaction chamber for at least $15 \mathrm{~min}$ to ensure complete standard transfer. Gaseous wall loss of GLV standards was determined by monitoring GLV concentration within the reaction chamber for six hours. GLV concentration did not decrease over the course of this experiment, however, and gaseous wall loss was found to be insignificant (Fig. S2). Since the bag volume was known, GLV calibration was completed by collecting a known volume and thereby known mass of GLV standards from the experimental chamber onto TD tubes. Ozone was then injected as a brief burst and sampling continued. Standard experiments were carried out at a $1: 1$ and $1: 2$ GLV-to$\mathrm{O}_{3}$ molar ratio to determine aerosol yields and measure reaction products. High GLV mass loadings were used to ensure 


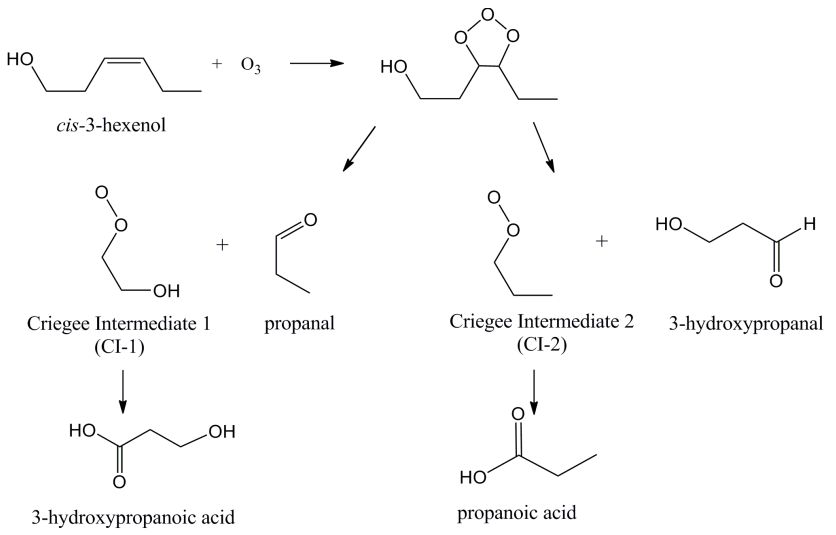

Scheme 1a. The ozonolysis of HXL is predicted to produce 3-hydroxypropanal and propanal along with the stabilized Creigee intermediates CI-1 and CI-2, which produce 3-hydroxy propanoic acid and propanoic acid, respectively, upon isomerization and hydration.

sufficient SOA mass and volatile product evolution for analysis.

Reaction rate constants $(k)$ for the ozonolysis of CHA and HXL were determined using experimental protocol described elsewhere (Grosjean et al., 1993; Grosjean and Grosjean, 1994). Briefly, pseudo-first-order reaction conditions were induced, whereby the GLV was present in excess of ozone, which was monitored throughout the reaction. A plot of $\ln \left([\text { Ozone }]_{t 0} /\left[\right.\right.$ Ozone $\left._{t}\right)$ vs. time yields a straight line with slope $k_{\text {observed }}$. From the rate expression of the reaction, $k=k_{\text {observed }} /[\mathrm{GLV}]_{t 0}$ (Fig. S6).

\section{Results}

\subsection{GLV standard chamber experiments}

\subsubsection{Single GLV system}

In order to characterize the emission profile of cut grass, a preliminary grass clipping ozonolysis experiment was performed. As shown in the total ion chromatogram (TIC) of GLVs emitted by cut grass (Fig. 2a), grass clippings emit a relatively complex mixture of volatile organics, dominated by CHA, 1-penten-3-ol and 2-pentanone (peaks 5, 4 and 3, respectively). Also present is a significant amount of $\mathrm{HXL}$ (peak 6), which, along with CHA, is a SOA precursor when subjected to ozone (Scheme 1a and b). This reactivity is clearly demonstrated by the TIC of the GLV mixture postozonolysis (Fig. 2b). 2-pentanone contains no chemical unsaturations and is therefore nonreactive with ozone, while 1-penten-3-ol, despite its unsaturations, does not appear to be highly reactive with ozone either, although chamber experiments with 1-penten-3-ol standards (Fig. S3) along with work done by Orlando et al. (2001) did indicate minimal re-

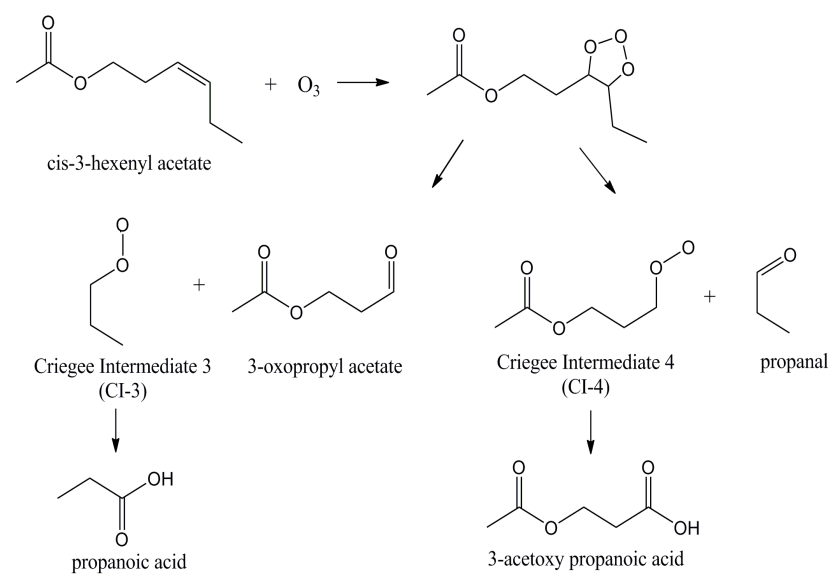

Scheme 1b.The ozonolysis of CHA is predicted to produce 3-oxopropyl acetate and propanal, along with two stabilized Criegee intermediates (CI-3 and CI-4) that produce propanoic acid and 3-acetoxy propanoic acid, respectively.

activity with ozone. Both headspace and grass clipping experiments had the same VOC emission profile, though the amount of each GLV differed between experiments, as shown in Table 2. Because of their relatively high emissions and their reactivity with ozone, we chose to "model" grass GLVs with CHA and HXL. Standards of each GLV were used to estimate their contribution to mow-induced SOA evolution, as described below.

A simplified scheme representing the ozonolysis of CHA is given in Scheme 1b. The ozonolysis of CHA is expected to form 3-oxopropyl acetate and propanal, along with two stabilized Criegee intermediates (CI-3 and CI-4) that produce propanoic acid and 3-acetoxy propanoic acid, respectively, upon isomerization and hydration (Hamilton et al., 2008; Grosjean and Grosjean, 1997). Upon ozonolysis of CHA (Fig. 3a), we observed the evolution of propanal and propanoic acid, but not 3-oxopropyl acetate or 3-acetoxy propanoic acid. The vapor pressure of 3-oxopropyl acetate $\left(5 \times 10^{-3} \mathrm{~atm}\right)$ is on the same order of magnitude as that of propanal and propanoic acid ( 0.4 atm and $4 \times 10^{-3}$ atm, respectively), suggesting that it should be measured in the gas phase. However, it was not observed in this work and experimental identification of 3-oxopropyl acetate by others has been tentative at best (Grosjean and Grosjean, 1999; Li et al., 2013; Hamilton et al., 2008). The estimated vapor pressure of 3-acetoxy propanoic acid $\left(4 \times 10^{-5} \mathrm{~atm}\right)$ is relatively low, suggesting that it may partition to the particle phase and/or that the GC-based method used herein was insufficient to quantify this species.

According to Scheme 1a, propanal, propanoic acid, 3hydroxypropanal and 3-hydroxypropanoic acid are expected products of the ozonolysis of HXL, of which we observed the evolution of both propanal and propanoic acid in the gas phase (Fig.3b). In accord with the estimated vapor 


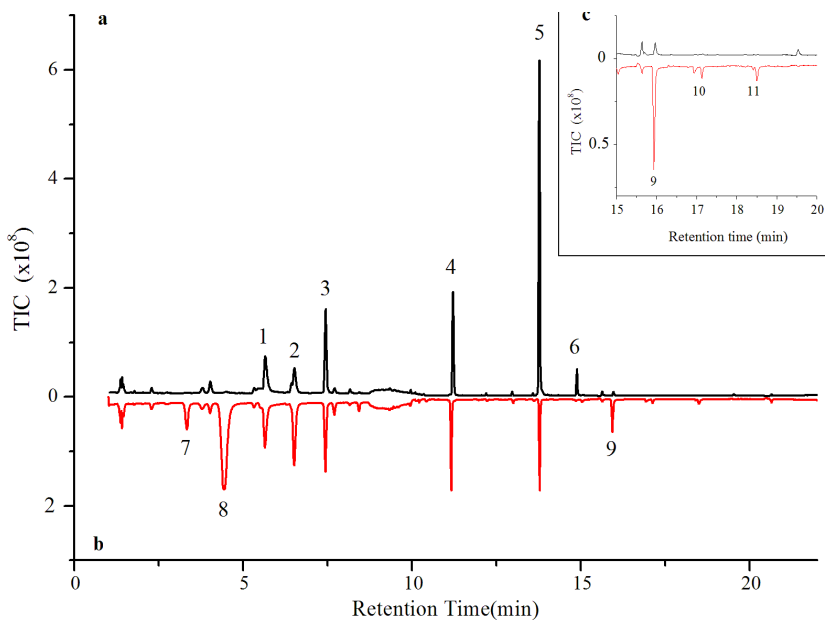

Fig. 2. Total ion chromatogram (TIC) of (a) VOCs emitted by grass clippings/headspace and (b) as a result of the ozonolysis of grass clippings/headspace. (a) GLVs emitted (black trace) show a complex mixture of volatile compounds with (3) 2-pentanone, (4) 1-penten-3-ol, (5) cis-3-hexenyl acetate and (6) cis-3-hexenol predominating. Other emitted VOCs include (1) methanol and (2) ethanol. Immediately post-ozonolysis (b) (red trace, $800 \mathrm{ppb}$ ozone), (5) cis-hexenyl acetate and (6) cis-hexenol signal dropped significantly indicating their reactivity with ozone, while chromatographic peaks from (7) propanal, (8) propenal, (9) acetic acid, (10) propanoic acid and (11) propenoic acid appeared, apparent products of cis-3-hexenyl acetate and/or cis-3-hexenol ozonolysis.

pressures of these species $\left(1 \times 10^{-7} \mathrm{~atm}\right.$ and $2 \times 10^{-5} \mathrm{~atm}$, respectively), we did not quantify 3-hydroxypropanal or 3hydroxypropanoic.

In addition to the predicted ozonolysis products, we also observed the evolution of 2-propenal and propenoic acid from both CHA and HXL and the production of acetic acid from CHA and acetaldehyde from HXL. Considerable work has been done by Hamilton et al. (2009) to identify the oxidation products of CHA and HXL, and, though they identify acetic acid, it is attributed to fragmentation of other species during their mass spectrometry ionization process. To our knowledge, this is the first known observation of these species as CHA and/or HXL ozonolysis products; however a full understanding of the mechanism leading to their formation is not clear and warrants additional work. As stated above, Scheme 1a and $\mathrm{b}$ are simplified representations of ozonolysis via the Criegee mechanism and do not take into account the many competing reaction pathways likely occurring simultaneously. These alternative reaction pathways are not within the scope of this work and are discussed elsewhere, yet still do not account for these products (Hamilton et al., 2009; Li et al., 2013).

The evolution of volatile ozonolysis products occurred as a concerted burst in both GLV systems, after which the signal for most products remained steady. In the ozonolysis of CHA, however, the propanal signal decreased over
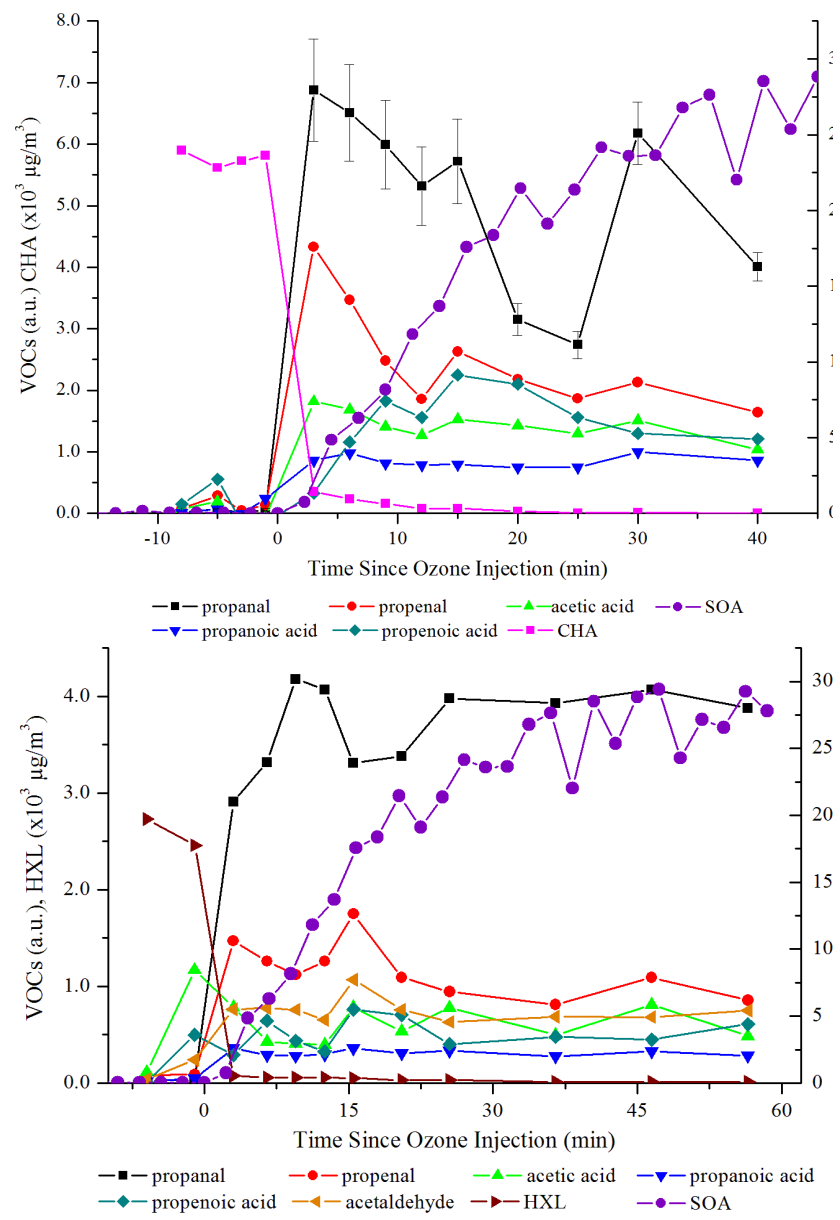

Fig. 3. Reaction profile for the ozonolysis of predominant grass GLVs; CHA (top) and HXL (bottom). Top panel: at time zero, $800 \mathrm{ppb}$ ozone was introduced to $5.7( \pm 0.1) \times 10^{3} \mu \mathrm{g} \mathrm{m}^{-3}$ of CHA, which resulted in SOA growth and the evolution of volatile products: propanal, propenal, propenoic acid, acetic acid and propanoic acid. Error bars $(1 \sigma)$ are shown only for propanal and are representative for all product evolution plots. Bottom panel: at time zero, $900 \mathrm{ppb}$ ozone was introduced to $2.6( \pm 0.2) \times 10^{3} \mu \mathrm{g} \mathrm{m}{ }^{-3} \mathrm{HXL}$, resulting in the evolution of SOA and the same volatile products as in the top panel, with the addition of acetaldehyde. Lines between data points drawn to aid the eye.

the course of $\sim 25 \mathrm{~min}$ before peaking again 30 min postozonolysis (Fig. 3a). This valley/peaked response suggests the presence of secondary reactions resulting in the consumption/production of propanal in the CHA system. While propanal was also measured as a product of HXL ozonolysis, the valley/peaked response was not observed for that system (Fig. 3b). Hamilton et al. (2009) propose a mechanism for the uptake of propanal by 3-hydroxypropanal, (product of HXL ozonolysis). Although we did not see evidence to support the uptake of propanal by HXL, the mechanism proposed by Hamilton et al. (2009) could apply to the CHA system, where the valley/peak response in propanal provides evidence for its reactive uptake. Based on a mechanism for 


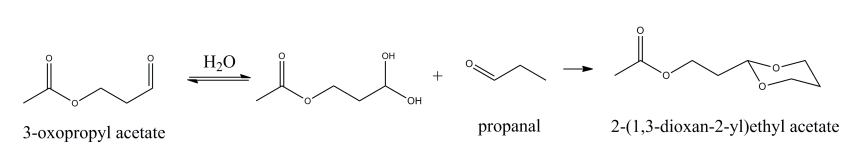

Scheme 2.Upon hydration, aldehyde functionality of 3-oxypropyl acetate could react with propanal, both predicted products of CHA ozonolysis (Scheme 1b), to produce 2-(1,3-dioxan-2-yl) ethyl acetate (VP $\left.5 \times 10^{-7} \mathrm{~atm}\right)$.

oligomer formation proposed by Hamilton et al. (2009), hydrated 3-oxopropyl acetate (CHA ozonolysis system) could react with propanal to produce 2-(1,3-dioxan-2-yl)ethyl acetate (Scheme 2). Based on this oligomer's estimated vapor pressure $\left(5 \times 10^{-7} \mathrm{~atm}\right)$, it would likely partition between both the particle and gaseous phase; however we did not observe this species using our GC-based methods (Reisen et al., 2003). This secondary reaction may also explain why 3oxopropyl acetate was not observed in CHA ozonolysis experiments.

In the general mechanism shown in Scheme 1b, propanoic acid is produced by ozonolysis of CHA. According to Li et al. (2013), the evolution of propanoic acid is a result of the $\alpha$-addition of water to CI-3 to form 1-hydroperoxypropan-1ol, which further decomposes to produce propanoic acid. $\mathrm{Li}$ et al. (2013) performed a kinetic investigation of the mechanism for CHA ozonolysis that confirmed that formation of 1-hydroperoxypropan-1-ol is the favored reaction pathway for CI-3. However, they found that the subsequent decomposition of 1-hydroperoxypropan-1-ol to propanoic acid and water has an energy barrier of $45.57 \mathrm{kcal} \mathrm{mol}^{-1}$ and is therefore not likely. Nevertheless, we observed propanoic acid as a product of CHA ozonolysis (Fig. 3a), and this is the only pathway proposed by Li et al. (2013) that leads to its formation. The highly oxidizing environment in which these reactions were performed could lead to further oxidation of propanal to produce propanoic acid, which may explain both the valley/peak behavior in the propanal signal and our observation of propanoic acid. However, we saw no evidence of the consumption of propanal coinciding with the production of propanoic acid in the reaction profile of CHA or HXL. Additionally, separate experiments showed that the ozonolysis of propanal alone did not oxidize to form propanoic acid when injected into the experimental chamber in the presence of high ozone (Fig. S4). The decomposition pathway leading to the formation of propanoic acid, (as proposed by Li et al. (2013), therefore, appears relevant, despite being energetically disfavored.

In the ozonolysis of each GLV, SOA evolution began immediately upon introduction of ozone into the reaction chamber and reached a maximum concentration in $\sim 60-90 \mathrm{~min}$ before decreasing slowly, likely due in part to particle loss to the chamber walls. Aerosol yields, $Y$, for CHA and HXL were calculated according to Eq. (1), where $\Delta[\mathrm{SOA}]$ is the maximum SOA concentration $\left(\mu \mathrm{g} \mathrm{m}^{-3}\right.$, assuming a particle density of $1.2 \mathrm{~g} \mathrm{~cm}^{-3}$ ) and $\Delta[\mathrm{GLV}]$ is the total amount of GLV consumed $\left(\mu \mathrm{g} \mathrm{m}^{-3}\right)$ at that SOA maximum (Odum et al., 1996).

$Y=\frac{\Delta[\mathrm{SOA}]}{\Delta[\mathrm{GLV}]} \times 100 \%$

Ozonolysis of CHA and HXL individually resulted in a measured aerosol yield of $0.24( \pm 0.08) \%$ and $0.26( \pm 0.1) \%$, respectively (Table 1). Particle loss to chamber walls was estimated according to Presto et al. (2005) and proved to be significant (Fig. S5), with an average wall deposition rate of $5.76 \times 10^{-4} \mu \mathrm{g} \mathrm{m}^{-3} \mathrm{~s}^{-1}$, which is greater than experimental chambers used by others $\left(2.5 \times 10^{-5}\right.$ and $1.0 \times 10^{-4} \mathrm{\mu g} \mathrm{m}^{-3} \mathrm{~s}^{-1}$ ) (Presto et al., 2005; Cocker et al., 2001; Carter et al., 2005; Wu et al., 2007). Given the large surface-to-volume ratio of our chamber, however $\left(5.3 \mathrm{~m}^{-1}\right)$, compared to that of others $\left(2.12 \mathrm{~m}^{-1}\right.$ to $\left.2.8 \mathrm{~m}^{-1}\right)$, a greater deposition rate is expected (Presto et al., 2005; Wu and Bauer, 2012). Unless otherwise noted, all subsequent reports of "measured" or "observed" SOA concentrations account for these wall losses.

Our wall loss coefficient was used to correct aerosol yield from GLV standard experiments. The corrected aerosol yields from ozonolysis of CHA and HXL were $1.2( \pm 1.1) \%$ and $3.3( \pm 3.1) \%$, respectively (Table 1$)$. The error associated with these yields is due to the variability in the amount of SOA formed in experiments. Our aerosol yield values are lower than the wall-loss-corrected aerosol yields reported by Hamilton et al. $(2008,2009)$, which were on the order of magnitude of prevalent monoterpenes: $9.5-24 \%$ for CHA and $8.6 \%$ for HXL. The chamber studies by Hamilton et al. $(2009,2009)$ were carried out at $1.6 \mathrm{ppm}$ GLV and $1.6 \mathrm{ppm}$ ozone, while our yield experiments were carried out at $1.0 \mathrm{ppm}$ GLV and $0.8 \mathrm{ppm}$ ozone. In both studies, the absolute amount of SOA produced was limited by the GLV species. The aerosol yield, however, is representative of the total amount of GLV consumed as a function of total amount of SOA produced, so it should be independent of starting conditions. The disparity between literature aerosol yields for these GLVs (Hamilton et al., 2008, 2009) and those reported herein is not readily explained; nonetheless, contrary to cyclic monoterpenes, we believe that linear alkene systems (such as GLVs) will produce lower SOA yields due to fragmentation of the precursors upon ozonolysis to produce higher-volatility products that will not enter the particle phase.

\subsubsection{Two GLV component mixtures}

As stated above, we measured several different, potentially reactive compounds in the complex mixture of GLVs emitted by grass clippings. Recent work by Shilling et al. (2013) in the CARES campaign indicates that VOC mixtures have a significant impact on SOA formation. With the goal of better 
Table 1. Experimental conditions and SOA yields for several GLV standard ozonolysis experiments, used to determine average aerosol yield for GLVs. Corrected SOA accounts for aerosol wall loss (Eq. S1 and Fig. S5 in the Supplement) and was used .to determine the average corrected SOA yield for CHA and HXL, $1.2( \pm 1.1) \%$ and $3.3( \pm 3.1) \%$ respectively, as indicated by the bolded text below.

\begin{tabular}{|c|c|c|c|c|c|c|c|c|}
\hline & Date & $\begin{array}{c}\text { CHA } \\
\text { consumed } \\
\left(\times 10^{3} \mu \mathrm{g} \mathrm{m}^{-3}\right)\end{array}$ & $\begin{array}{c}\text { HXL } \\
\text { consumed } \\
\left(\times 10^{3} \mu \mathrm{g} \mathrm{m}^{-3}\right)\end{array}$ & $\begin{array}{c}\text { Ozone } \\
\text { injected (ppb) }\end{array}$ & $\begin{array}{l}\text { Measured SOA } \\
\quad\left(\mu \mathrm{g} \mathrm{m}^{-3}\right)\end{array}$ & $\begin{array}{l}\text { Corrected SOA } \\
\quad\left(\mu \mathrm{g} \mathrm{m}^{-3}\right)\end{array}$ & $\begin{array}{c}\text { Measured aerosol } \\
\text { yield }\end{array}$ & $\begin{array}{c}\text { Corrected aeroso } \\
\text { yield }\end{array}$ \\
\hline \multicolumn{9}{|l|}{ HXL } \\
\hline & $10 / 01 / 2013$ & & 2.08 & 800 & 6.3 & 60.1 & $0.30 \%$ & $2.88 \%$ \\
\hline & $18 / 02 / 2013$ & & 5.47 & 1000 & 11.8 & 22.8 & $0.22 \%$ & $0.42 \%$ \\
\hline & $23 / 04 / 2013$ & & 2.72 & 950 & 27.5 & 178.0 & $1.01 \%$ & $6.54 \%$ \\
\hline & & & & & & average & $0.26 \%$ & $3.28 \%$ \\
\hline & & & & & \multicolumn{2}{|c|}{ standard deviation } & $0.1 \%$ & $3.1 \%$ \\
\hline \multicolumn{9}{|l|}{$\mathrm{CHA}$} \\
\hline & $10 / 04 / 2013$ & 5.61 & & 500 & 7.1 & 25.4 & $0.13 \%$ & $0.45 \%$ \\
\hline & $10 / 04 / 2013$ & 5.86 & & 3400 & 15.3 & 33.4 & $0.26 \%$ & $0.57 \%$ \\
\hline & $12 / 04 / 2013$ & 5.76 & & 950 & 18.7 & 67.2 & $0.32 \%$ & $1.17 \%$ \\
\hline & $18 / 04 / 2013$ & 2.97 & & 1500 & 7.4 & 21.0 & $0.25 \%$ & $0.70 \%$ \\
\hline & $26 / 04 / 2013$ & 2.86 & & 1100 & 17.8 & 91.1 & $0.62 \%$ & $3.19 \%$ \\
\hline & & & & & & average & $0.24 \%$ & $1.22 \%$ \\
\hline & & & & & \multicolumn{2}{|c|}{ standard deviation } & $0.08 \%$ & $1.1 \%$ \\
\hline
\end{tabular}

Table 2. Experimental conditions, SOA and GLV results for several grass clipping and headspace experiments. Ozone concentration was $\sim 800$ pbb for each experiment. Predicted SOA concentration was determined using initial GLV emissions and wall-loss-corrected aerosol yields. RSD is the relative standard error in the value to the left. RSD of predicted SOA is driven by the high uncertainty in the aerosol yield calculation (Table 1). RSD in HXL and CHA concentrations and masses determined using each GLV calibration.

\begin{tabular}{|c|c|c|c|c|c|c|c|c|c|c|c|c|c|c|}
\hline & Date & $\begin{array}{c}\mathrm{SOA} \\
\left(\# \mathrm{~cm}^{-3}\right)\end{array}$ & $\begin{array}{c}\mathrm{SOA} \\
\left(\mu \mathrm{g} \mathrm{m}^{-3}\right)\end{array}$ & $\begin{array}{l}\text { Wall Loss } \\
\text { Corrected SOA } \\
\left(\mu \mathrm{g} \mathrm{m}^{-3}\right)\end{array}$ & $\begin{array}{l}\text { Predicted SOA } \\
\qquad\left(\mu \mathrm{g} \mathrm{m}^{-3}\right)\end{array}$ & RSD & $\begin{array}{c}\mathrm{HXL} \\
\left(\mu \mathrm{g} \mathrm{m}^{-3}\right)\end{array}$ & RSD & $\begin{array}{c}\text { HXL per m }{ }^{2} \text { lawn } \\
\left(\mu \mathrm{g} \mathrm{m}^{-2}\right)\end{array}$ & RSD & $\begin{array}{c}\text { CHA } \\
\left(\mu \mathrm{g} \mathrm{m}^{-3}\right)\end{array}$ & RSD & $\begin{array}{l}\text { CHA per } \mathrm{m}^{2} \text { lawn } \\
\quad\left(\mu \mathrm{g} \mathrm{m}^{-2}\right)\end{array}$ & RSD \\
\hline \multirow{4}{*}{ Clippings } & $23 / 10 / 2012$ & 11835 & 39 & 55 & 9.55 & 2.51 & 137 & 0.09 & 0.14 & 0.04 & 2100 & 0.04 & 2.29 & 0.04 \\
\hline & $27 / 10 / 2012$ & 6077 & 16 & 27 & 1.21 & 1.12 & 31.4 & 0.49 & 0.022 & 0.19 & 75.7 & 0.87 & 0.05 & 0.87 \\
\hline & $06 / 11 / 2012$ & 46102 & 82 & 113 & 10.05 & 4.12 & 39.2 & 0.39 & 0.033 & 0.18 & 3650 & 0.04 & 3.10 & 0.04 \\
\hline & $28 / 05 / 2013$ & 73630 & 120 & 153 & 3.74 & 2.41 & 56.6 & 0.30 & 0.0079 & 0.03 & 785 & 0.04 & 0.11 & 0.04 \\
\hline \multirow{4}{*}{ Headspace } & $23 / 10 / 2012$ & 1190 & 5.9 & 8.8 & 43.56 & 1.58 & 885 & 0.03 & 1.7 & 0.02 & 6060 & 0.04 & 11.36 & 0.42 \\
\hline & $27 / 10 / 2012$ & 348 & 2.9 & 3.8 & 13.34 & 3.34 & 120 & 0.13 & 0.19 & 0.12 & 3920 & 0.04 & 6.35 & 0.49 \\
\hline & 06/11/2012 & 1422 & 5.2 & 16 & 9.66 & 1.44 & 205 & 0.22 & 0.089 & 0.16 & 1220 & 0.04 & 0.53 & 0.39 \\
\hline & $08 / 05 / 2013$ & 793 & 6.8 & 12 & 5.59 & 1.60 & 113 & 0.11 & 0.23 & 0.11 & 788 & 0.03 & 1.60 & 0.35 \\
\hline
\end{tabular}

understanding SOA formation and yield under environmentally relevant conditions (where VOCs exist as a mixture), we performed two-component ozonolysis experiments with CHA and HXL. In one experiment, ozone was introduced to a GLV mixture containing a $1: 1$ mole ratio mix of the two components, while a second experiment used a $1: 5$ mole ratio of HXL to CHA, analogous to that measured from real grass clippings.

The reaction profile for the ozonolysis of the $1: 1 \mathrm{GLV}$ mixture (Fig. 4) shows that the majority of both CHA and HXL is consumed within the first five min of the reaction. SOA and volatile product evolution occurred immediately, reaching maxima less than $20 \mathrm{~min}$ into the reaction. SOA and volatile product concentrations remained relatively constant post-maxima, and propanal did not exhibit the peak/valley trend observed in the CHA-only ozonolysis experiments. Qualitatively, the 1:1 GLV mix reaction profile bares a strong semblance to that of the HXL-only ozonolysis profile (Fig. 3b), suggesting that, in an equimolar concentration, $\mathrm{HXL}$ is more reactive to ozonolysis than CHA. The reaction rate constants we calculated also indicate that $\mathrm{HXL}(\mathrm{k}=$ $6.7 \times 10^{-17} \mathrm{~cm}^{3} \mathrm{~s}^{-1}$ molecule $\left.{ }^{-1}\right)$ is more reactive to ozone than CHA $\left(3.6 \times 10^{-17} \mathrm{~cm}^{3} \mathrm{~s}^{-1}\right.$ molecule $\left.{ }^{-1}\right)$ (Fig. S6). These reaction rates agree well with those found by Kirstine and Galbally (2004) $\left(5.4 \times 10^{-17} \mathrm{~cm}^{3} \mathrm{~s}^{-1}\right.$ molecule ${ }^{-1}$ for CHA and $6.4 \times 10^{-17} \mathrm{~cm}^{3} \mathrm{~s}^{-1}$ molecule ${ }^{-1}$ for HXL), who used the relative reaction rate method and also found that HXL was more reactive to ozonolysis. Using the wallloss-corrected aerosol yields measured in this work and the initial mass of GLVs injected into the chamber, total SOA production for the $1: 1 \mathrm{mix}$ was expected to reach 125 $( \pm 85) \mu \mathrm{g} \mathrm{m}^{-3}$. However, the maximum wall-loss-corrected SOA concentration measured was $9.8 \mu \mathrm{g} \mathrm{m}^{-3}$. 


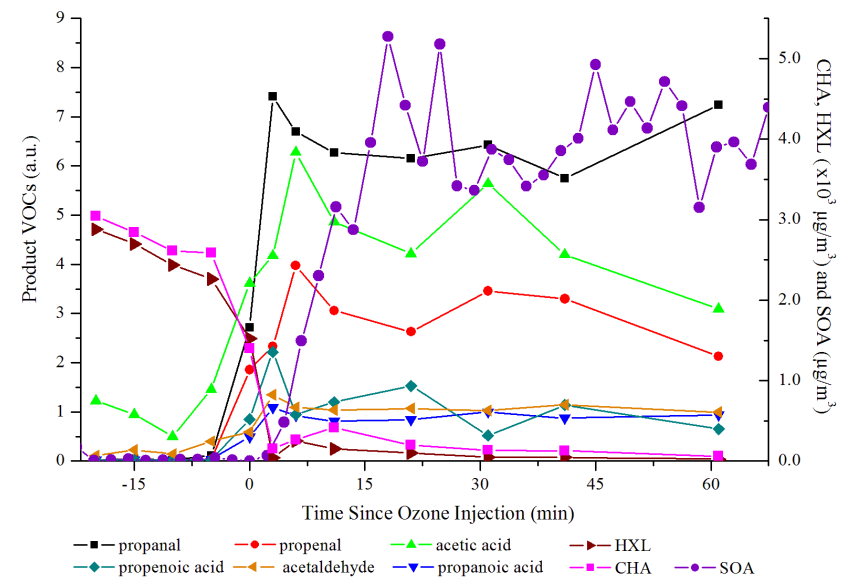

Fig. 4. Reaction profile of the ozonolysis of a $1: 1 \mathrm{mix}$ of $\mathrm{CHA}$ and HXL (initial concentration $2.8( \pm 0.2) \times 10^{3} \mu \mathrm{g} \mathrm{m}^{-3}$ each). $900 \mathrm{ppb}$ ozone was injected at time zero, after which SOA and volatile products (propanal, propenal, propenoic acid, acetic acid, propanoic acid, acetaldehyde) increased in signal. Lines between data points drawn to aid the eye.

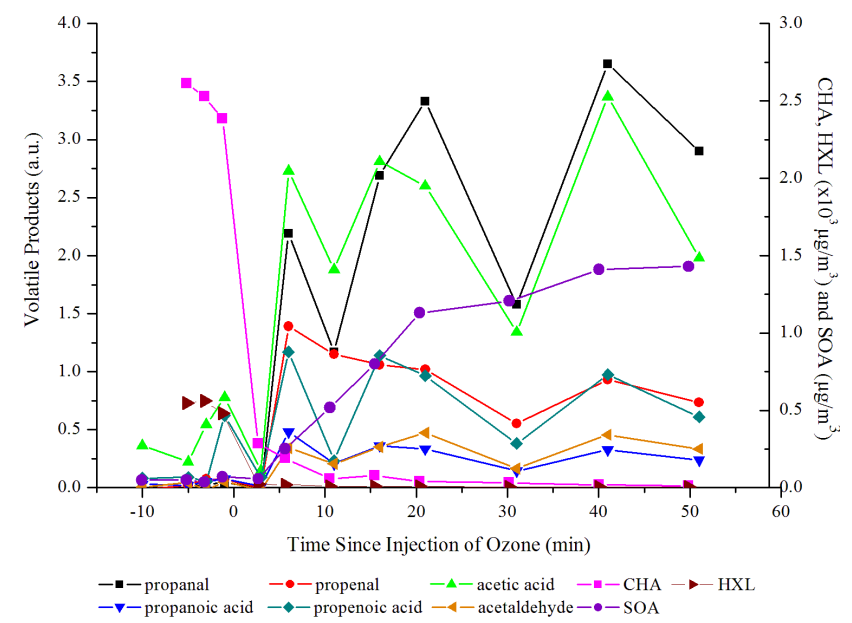

Fig. 5. Reaction profile of the ozonolysis of a 5:1 mix of CHA and HXL (initial concentration $2.5( \pm 0.1) \times 10^{3} \mu \mathrm{g} \mathrm{m}^{-3}$ and 0.5 $( \pm 0.04) \times 10^{3} \mu \mathrm{g} \mathrm{m}^{-3}$, respectively). $800 \mathrm{ppb}$ ozone was injected at time zero, after which SOA and volatile products (propanal, propenal, propenoic acid, acetic acid, propanoic acid, acetaldehyde) increased in signal. Lines between data points drawn to aid the eye.

The ozonolysis of 1 HXL: 5 CHA mix also resulted in the rapid consumption of GLVs and the immediate evolution of SOA and volatile products (Fig. 5). This reaction profile more closely approximates the CHA-only reaction profile (Fig. 3b), with both propanal and acetic acid exhibiting the valley/peak trend. This suggests the occurrence of the same secondary reactions observed in the CHA-only system. Wallloss-corrected aerosol yields predicted the formation of 50 $( \pm 17) \mu \mathrm{g} \mathrm{m}^{-3}$ of SOA, much more than the maximum wallloss-corrected SOA concentration observed: $5.3 \mu \mathrm{g} \mathrm{m}^{-3}$. The

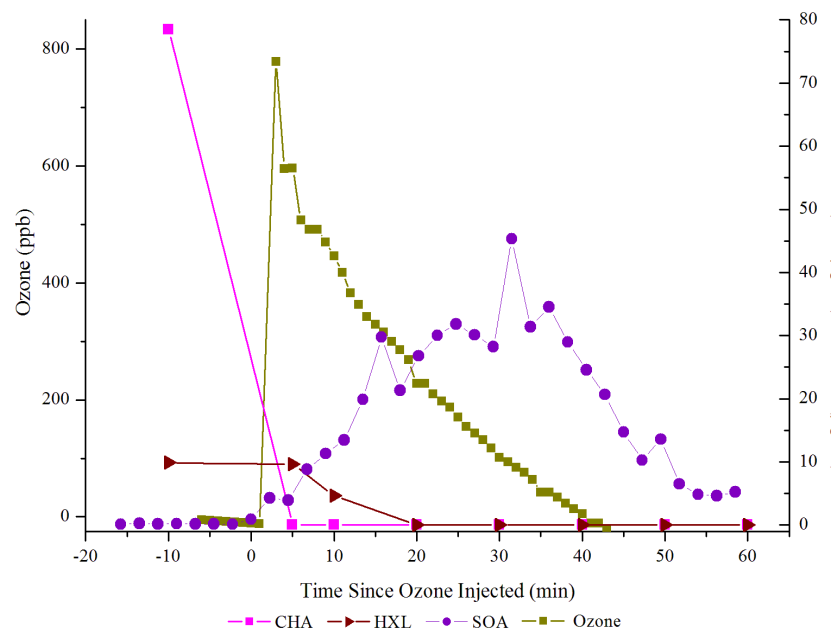

Fig. 6a. Approximately $0.5 \mathrm{~kg}$ of grass clippings were placed in the experimental chamber, which was then filled with zero air. Initial concentrations of CHA and HXL were $8.0( \pm 2) \times 10^{2} \mu \mathrm{g} / \mathrm{m}^{3}$ and $1.0( \pm 0.8) \times 10^{2} \mu \mathrm{g} / \mathrm{m}^{3}$, respectively. At time zero $\sim 800 \mathrm{ppb}$ ozone was injected and both CHA and HXL concentrations dropped below the instrument detection limit within the first five min of the reaction, while SOA concentration increased for about $30 \mathrm{~min}$ before reaching a maximum of $\sim 91 \mu \mathrm{g} / \mathrm{m}^{3}$ (wall-loss-corrected). Lines between data points drawn to aid the eye.

disparity between the measured and predicted SOA concentrations in mixture experiments could suggest the presence of secondary chemistry that resulted in the consumption of GLVs without the production of SOA.

\subsection{Grass ozonolysis reaction profile}

As stated above, although grass clippings emitted several volatile species, the GLV profile was dominated by CHA, HXL and 1-penten-3-ol (Fig. 2a), all of which are unsaturated and thereby have the potential to undergo oxidation by ozone. Despite its unsaturation, however, 1-penten-3-ol showed limited reactivity with ozone (Fig. S3). Initial CHA, HXL, and ozone concentrations for several experiments are listed in Table 2 and are on the same order of magnitude and mole ratio as the "1:5 GLV standard mixture" experiment above. In the ozonolysis of both grass headspace and grass clippings, these three GLVs decreased in signal (albeit to a much smaller extent for 1-penten-3-ol), while that of their corresponding gas-phase oxidation products, propanal, propanoic acid, and acetic acid, increased. As in the GLV standard reactions, we also observed the evolution of propenal, propenoic acid, acetic acid and acetaldehyde, which have not previously been observed as products of grass ozonolysis.

A typical reaction profile for the ozonolysis of grass clippings is shown in Fig. 6a and b. The injection of $800 \mathrm{ppb}$ ozone (at time 0) resulted in an initial burst of SOA. High ozone loadings were used to ensure a complete oxidation of 


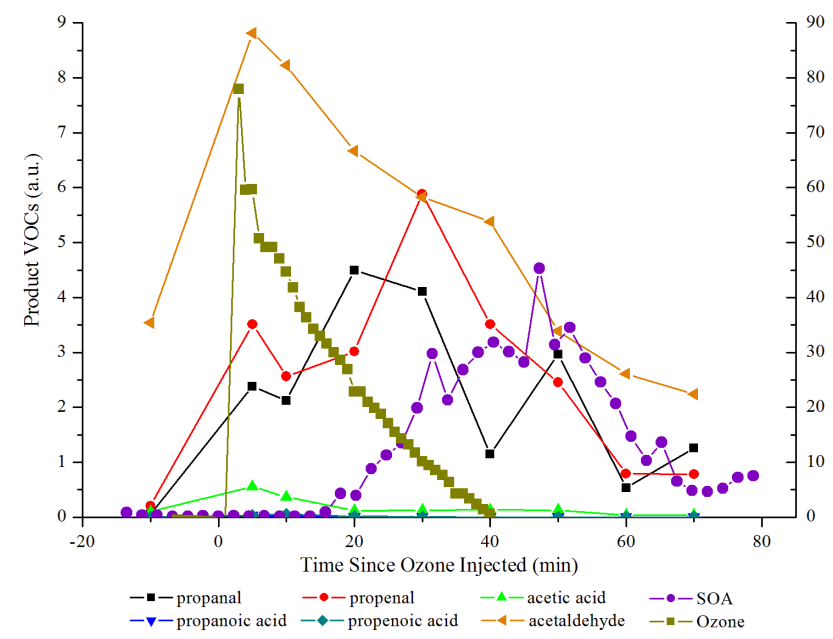

Fig. 6b. In addition to the evolution of SOA, the ozonolysis of grass clippings also resulted in the evolution of several volatile products, including propanal, propenal, acetaldehyde and acetic acid. Trace amounts of propenoic acid, and propanoic acid, were measured. Several of these volatiles products have not previously been reported as products of CHA or HXL ozonolysis. Lines between data points drawn to aid the eye.

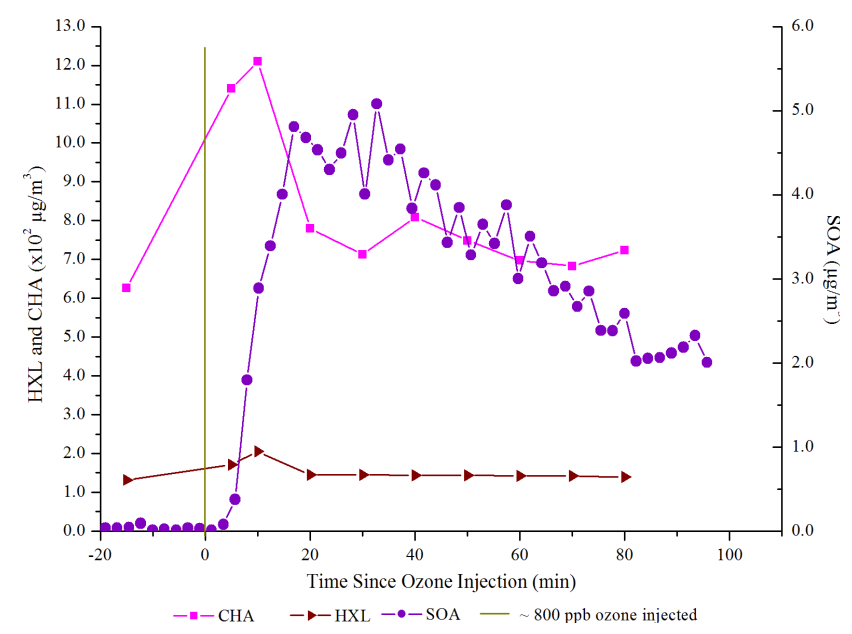

Fig. 7a. Zero air was flushed through grass clippings and into the experimental chamber, carrying with it GVLs contained in the grass headspace. Maximum concentrations of CHA and HXL (12 $( \pm 1) \times 10^{2} \mu \mathrm{g} \mathrm{m}^{-3}$ and $2.05( \pm 0.01) \times 10^{2} \mu \mathrm{g} \mathrm{m}^{-3}$, respectively $)$ were measured post-ozonolysis, which we believe was due to incomplete mixing within the experimental chamber before ozone injection. Ozone data were not available, but at time zero $\sim 800 \mathrm{ppb}$ ozone was injected (indicated by vertical line) and within $20 \mathrm{~min}$ HXL concentration dropped below the instrument detection limit while SOA reached its maximum wall-loss-corrected concentration $\left(15.7 \mu \mathrm{g} \mathrm{m}^{-3}\right)$. CHA remained relatively constant after the first $20 \mathrm{~min}$ of the reaction $\left(0.74( \pm 0.05) \times 10^{3} \mu \mathrm{g} \mathrm{m}^{-3}\right)$ and was never completely consumed. Lines between data points drawn to aid the eye.

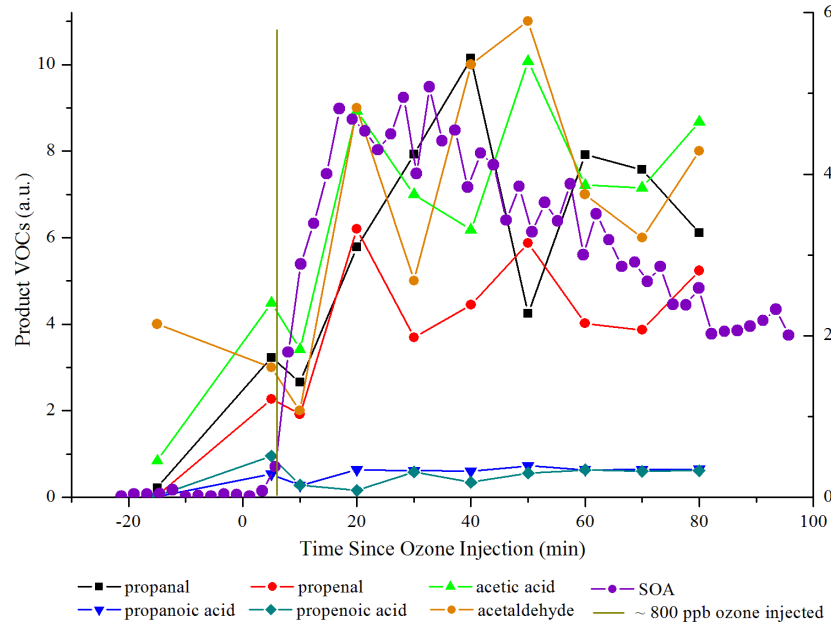

Fig. 7b. In addition to the evolution of SOA, the ozonolysis of grass headspace resulted in the evolution of several volatile products, including propanal, propenal, propenoic acid, acetic acid, propanoic acid, acetaldehyde, several of which have not previously been reported as products of CHA or HXL ozonolysis. Lines between data points drawn to aid the eye.

all GLVs and to model GLV standard ozonolysis experiments (Table 1), but do not represent atmospherically relevant conditions, as discussed below. In several headspace and grass clipping experiments, the resultant SOA concentration increased to its maximum (up to $\sim 50 \mu \mathrm{g} \mathrm{m}^{-3}$ and $\sim 215 \mu \mathrm{g} \mathrm{m}^{-3}$ in headspace and clipping experiments, respectively) approximately 20-30 min post-ozonolysis before decreasing rapidly to background levels. As described above, in clipping experiments, the grass was placed inside the reaction chamber, providing a very large surface area for enhanced SOA loss. If SOA "grass loss" were significant, one might expected SOA levels in grass clipping experiments to decrease more quickly than in grass headspace experiments. However, the SOA loss in both headspace and clipping experiments occurred at similar rates, suggesting that the rapid decrease in SOA concentration in clipping experiments is not due to sorption to the grass clippings and cannot be explained entirely by wall loss mechanisms. The mechanism for SOA loss in grass clipping and headspace experiments is not understood but may involve secondary reactions that increase the volatility of SOA as it ages. Understanding SOA reactivity and loss warrants additional work.

In both headspace (reaction profile in Fig. 7a and b) and clipping experiments, volatile products increased as a concerted burst within the first 10 min of ozone injection. In the first $40 \mathrm{~min}$ of headspace experiments, $50 \%$ of CHA, HXL and 1-penten-ol was consumed, while more than $90 \%$ of the ozone was consumed. CHA concentration decreased then remained constant once ozone had been depleted. Propenal and acetaldehyde increased steadily post-ozonolysis. Propanal increased, but exhibited a peak-valley behavior similar to that 
in GLV standards experiments. All other VOC products decreased post-ozonolysis.

In grass clipping experiments, CHA and HXL were completely consumed within the first $\sim 20$ min of the reaction, while ozone concentration fell to background levels $\sim 45 \mathrm{~min}$ post-ozonolysis. GLV concentrations were lower in grass clipping experiments than in headspace experiments, but this may have been a result of experimental design, as grass clippings were not allowed to equilibrate in the reaction chamber for more than a few minutes before ozone was injected. Acetic acid, propanoic acid and propenoic acid signal fell after an initial burst, while propanal remained steady after its post-ozonolysis increase (similar to HXL standard experiments).

Applying the wall-loss-corrected aerosol yields above (Eq. 1) to the measured GLV emission rates in both headspace and clipping experiments, theoretical SOA production could be estimated (Table 2). The observed, wallloss-corrected SOA concentration in grass headspace experiments was less than predicted by aerosol yields with a $-120 \%$ difference. This difference was similar to the degree of disparity in predicted vs. measured predicted vs. measured SOA mass in the $1: 1$ the $1: 1 \mathrm{mix}$ ozonolysis experiment (-115\% difference), suggesting the 1:1 mix may model SOA production from grass headspace to some degree.

The observed, wall-loss-corrected SOA production in grass clipping experiments was much greater than aerosol yields predicted $(+170 \%)$. The ozonolysis of neither the $1: 1$ mix nor the $1: 5$ mix resulted in the overproduction of SOA, suggesting that neither mix accurately models grass clippings. Based on the corrected SOA yields, when summed, HXL and CHA account for only a small fraction of observed SOA $(15( \pm 13) \%)$. Because GLVs are continuously emitted by grass clippings, they likely represent a continuous source of SOA, rather than a one-time burst, which may contribute to the observed disparity between predicted and measured SOA. This disparity may also suggest that other, potentially important processes are contributing to SOA evolution by the mowing and subsequent oxidation of grass, as will be discussed below.

The disparity in SOA yield between grass clippings and grass headspace ozonolysis experiments could be due to either the enhancement of SOA growth in clippings (i.e., chemical wounding by ozone, as discussed below) or the suppression of SOA growth in headspace and mixed GLV standard experiments. The presence of some volatile species (i.e., isoprene) has been shown to inhibit new particle formation (Kiendler-Scharr et al., 2009). Recently, Mentel et al. (2013) found that HXL suppressed SOA formation from the ozonolysis of $\alpha$-pinene as a result of competing reactions with $\mathrm{OH}$. In a mixture of reactive VOCs, we might expect the VOC with the greatest reaction rate for a given oxidant to consume that oxidant preferentially and contribute most to the resultant product profile. For example, in the case of $\alpha$-pinene and HXL provided by Mentel et al.,
(2013), both the $\mathrm{O}_{3}$ and the $\mathrm{OH}$ rate constant for $\alpha$-pinene $\left(0.28-3.3 \times 10^{-16}\right.$ and (5-6) $\times 10^{-11} \mathrm{~cm}^{3}$ molecule ${ }^{-1} \mathrm{~s}^{-1}$, respectively) are less than that for HXL $\left(7 \pm 3 \times 10^{-17}\right.$ and $1.1 \times 10^{-10} \mathrm{~cm}^{3}$ molecule $\mathrm{s}^{-1} \mathrm{~s}^{-1}$, respectively), suggesting that both $\mathrm{O}_{3}$ and $\mathrm{OH}$ would preferentially oxidize HXL over $\alpha$-pinene. (Dash et al., 2013; Kirstine and Galbally, 2004). Since HXL has a smaller aerosol yield than $\alpha$-pinene, this preferential reactivity would suppress total SOA growth. Similarly, SOA growth in the grass headspace experiments could have been suppressed by the preferential oxidation of some low-aerosol-yield volatile species that were not detectable using our methods. This rationalization, however, does not explain the low aerosol yields observed in the ozonolysis experiments using mixtures of GLV standards.

As demonstrated by the disparity between predicted and actual SOA production, the ozonolysis of HXL or CHA alone does not accurately represent SOA from the ozonolysis of grass clippings or grass headspace. Mixtures of the two dominant reactive GLVs are more representative of the grass headspace system than the grass clippings, and produce similar trends in SOA growth and volatile product evolution. Therefore, predictions of atmospheric SOA mass loading using even these two predominant GLVs underestimate actual SOA loading resulting from lawn mowing.

\section{Contribution of lawn mowing to atmospheric SOA}

The site area chosen for this study was a residential, suburban neighborhood in close proximity to an industrial, urban landscape. A geospatial analysis of the 131-acre area around the study site showed that lawns and turfgrass comprise $27.5 \%$ of the total land cover in this suburban neighborhood (36 acres). Remaining land cover was comprised of wooded lots, scrub brush and impervious surfaces such as roads, driveways and rooftops. Lawn mowing has been estimated to produce $\sim 1.3 \times 10^{3} \mathrm{gdw} \mathrm{m}^{-2} \mathrm{yr}^{-1}$ of clippings (where gdw is grams dry weight) (Fig. S7). Stevenson (2010) estimated that New England homeowners mow their lawn 20 times annually, so we predict that approximately $66 \mathrm{gdw} \mathrm{m}^{-2}$ mowing $^{-1}$ of grass clippings are produced by New England lawns. Using the measured GLV emissions normalized to the mass of grass ( $\mathrm{gdw}$ ) collected in each experiment, we estimate that lawns in this typical suburban neighborhood have the capacity to emit $8.66( \pm 0.08) \mu \mathrm{g} \mathrm{m}^{-2}$ of CHA and $1.21( \pm 0.06) \mu \mathrm{g} \mathrm{m}^{-2}$ of HXL as a concerted burst upon mowing. Based on our wall-loss-corrected aerosol yields, these GLVs have the capacity, therefore, to contribute $177 \mathrm{mg} \mathrm{SOA}$ to the neighborhood airshed, annually.

However, as shown above, the actual SOA mass measured due to the ozonolysis of grass clippings is much greater than predicted by our yields, so the $177 \mathrm{mg} \mathrm{yr}^{-1}$ estimate is not truly representative of the potential contribution of lawn mowing to airshed SOA levels. Using the measured SOA as a function of grass mass (gdw) in a "top-down" approach 
to this estimate, we predict that $0.9 \mu \mathrm{ggdw}^{-1} \mathrm{SOA}$ could be produced upon mowing, where $\mu \mathrm{gdw}^{-1}$ represents the mass of SOA produced $(\mu \mathrm{g})$ as a function of grass dry weight in grams (gdw). For our study site, this SOA production rate corresponds to $47 \mu \mathrm{g}$ SOA per square meter mowed, or $940 \mu \mathrm{g} \mathrm{m}^{-2}$, annually (Fig. S7). Based on reported emissions from forested landscapes and the fraction of forested landscape in the region of the study area, isoprene and monoterpenes are estimated to contribute 2500 and $2000 \mu \mathrm{g} \mathrm{m}^{-2}$ SOA annually, respectively (Guenther et al., 1994; Zheng et al., 2013). Lawn mowing, therefore, has the potential to emit a significant amount of SOA, comparable to the two predominant SOA sources, as a concerted burst to the local airshed.

As stated above, ozone was introduced to the experimental chamber as a one-time burst that resulted in concentrations of about $800 \mathrm{ppb}$, which is much greater than average ozone levels in Chittenden County, VT ( $\sim 60 \mathrm{ppb})$ (US Environmental Protection Agency, 2013). Eight hundred (800) ppb ozone was used in preliminary grass clipping experiments to ensure a sufficient concentration to result in SOA growth and was used in subsequent GLV standard and grass experiments for the sake of consistency. Though ambient ozone concentrations are lower than the experimental ones used herein, they are expected to be elevated on warm, sunny days, the same time lawn mowing is expected to occur. Additionally, ozone plumes can be transported several hundred kilometers from industrial or urban sources to rural sites where they can interact with BVOCs (Mao et al., 2006; Bertschi and Jaffe, 2005; Wang et al., 2006). For example, plumes originating in New York City, NY, can extend $600 \mathrm{~km}$ and contain up to $160 \mathrm{ppb}$ ozone (Lee et al., 2011). The prevailing winds in Essex Junction, VT, are from the west, putting the study site five miles downwind from the City of Burlington, VT, and many industrial areas, which may introduce an additional source of ozone. Therefore, it is possible that local ozone levels in rural landscapes could be elevated during mowing events. Additionally, in the field any consumed ozone is expected to be replenished by other sources that are prevalent in the atmosphere, whereas in our experiments ozone was injected as a single burst (Steinbrecher et al., 2000). Exposure to a concerted burst of $800 \mathrm{ppb}$ ozone is admittedly different than an exposure to $100 \mathrm{ppb}$ over the course of 8 hours, which would be a more representative exposure scenario, but such exposures will require use of a continuous flow reaction chamber. Exposure to ozone itself has also been shown to cause VOC emission in several plant species (Heiden et al., 2003; Woodbury et al., 1994; Kivimäenpää et al., 2013; Miresmailli et al., 2013). Depending on the reactivity of these VOCs, they may also undergo ozonolysis and contribute to additional SOA mass and could help explain the disparity between SOA yields in headspace vs. clipping experiments. We did not detect the emission of VOCs by grass clippings as a result of ozonolysis; however they may have been immediately consumed by yet more ozone in the reaction chamber. Additional work is necessary to understand ozone-induced VOC emission by grasses and their subsequent reactivity with ozone.

Despite our efforts to model real-world conditions in our experiments, the atmosphere offers complexities that may lead to additional SOA evolution as a result of lawn mowing. Work done by Kirstine et al. (2004), Orlando et al. (2001), and Papagani et al. (2001) has shown that grass GLVs have considerable reactivity with nitrate and hydroxyl radicals. Hamilton et al. (2009) predicted a $3.1 \%$ and $0.9 \%$ aerosol yield from the photooxidation of HXL and CHA, respectively. Given the established reactivity of GLVs with other atmospheric oxidants, additional work should be done to characterize the volatile products and SOA produced from the photooxidation of GLVs.

This work focused on the interaction of two predominant GLVs and their roles in SOA formation; however there is also growing evidence to indicate that the presence of ASOA and AVOC in conjunction with BVOC synergistically enhances the production of SOA (Shilling et al., 2013; Emanuelsson et al., 2013; Hildebrandt et al., 2011). The relatively large ratio of land cover encompassed by lawns in suburban neighborhoods represent a source of BVOCs, which by definition are in close proximity to urban and industrial sources of BVOCs and BSOA, as well as elevated concentrations of oxidants. There are several sources of A/BVOCs and A/BSOA at the urban-suburban interface that provide ample opportunity for interaction. For example, the emissions of lawn mowers themselves have been found to contribute $4 \mu \mathrm{g} \mathrm{m} \mathrm{m}^{-3}$ of aerosol during a mowing event, likely from unspent fuel emissions and agitated plant debris and soil (Drewnick et al., 2008). Additional work is needed to determine whether an anthropogenic enhancement effect drives additional SOA production from the ozonolysis of grass clippings, not seen in headspace or GLV standard experiments. These experiments should include the ozonolysis of GLVs in the presence of seed aerosols, which would serve as a proxy to ambient atmospheric particulate matter or primary organic aerosols and should also involve GLV oxidation in the presence of AVOCs and oxidants.

\section{Conclusions}

Though many volatile species are emitted by grass clippings, the profile is dominated by CHA and HXL, which are easily oxidized by ozone to produce significant amounts of SOA, in addition to a suite of oxygenated volatile products. Herein we report the first known observation of propenal and propenoic acid as ozonolysis products of both CHA and HXL, as well as support other products previously reported in the literature (Hamilton et al., 2009; Li et al., 2013; Reisen et al., 2003; O’Dwyer et al., 2010; Aschmann et al., 1997). We found that the mowing of lawns has the potential to contribute up to $47 \mu \mathrm{g}$ of SOA to the atmosphere per $\mathrm{m}^{2}$ of lawn, which cannot be modeled solely by the ozonolysis of CHA 
and/or HXL. While these two GLVs were found to produce SOA upon ozonolysis, they each largely underpredict SOA mass loading from ozonolysis of grass clippings. The disparity between measured and predicted SOA mass loading may be rectified by incorporating additional oxidation sources, BVOCs, AVOCs and ASOA, which may contribute to an anthropogenic enhancement effect in grass clipping oxidation.

The ozonolysis of two-component mixtures of CHA and HXL confirms that the chemical processes leading to SOA formation could be better modeled by mixtures than by single-component systems. However, the chemical processes involved are not well understood and warrant additional work (Carlton et al., 2010; de Gouw et al., 2005; Shilling et al., 2013; Spracklen et al., 2011).

\section{Supplementary material related to this article is available online at http://www.atmos-chem-phys.net/14/ 797/2014/acp-14-797-2014-supplement.pdf.}

Acknowledgements. This material is based upon work supported by the National Science Foundation under grant no. CHE-1213632.

Edited by: S. A. Nizkorodov

\section{References}

Aiken, A. C., Salcedo, D., Cubison, M. J., Huffman, J. A., DeCarlo, P. F., Ulbrich, I. M., Docherty, K. S., Sueper, D., Kimmel, J. R., Worsnop, D. R., Trimborn, A., Northway, M., Stone, E. A., Schauer, J. J., Volkamer, R. M., Fortner, E., de Foy, B., Wang, J., Laskin, A., Shutthanandan, V., Zheng, J., Zhang, R., Gaffney, J., Marley, N. A., Paredes-Miranda, G., Arnott, W. P., Molina, L. T., Sosa, G., and Jimenez, J. L.: Mexico City aerosol analysis during MILAGRO using high resolution aerosol mass spectrometry at the urban supersite (T0) - Part 1: Fine particle composition and organic source apportionment, Atmos. Chem. Phys., 9, 6633-6653, doi:10.5194/acp-9-6633-2009, 2009.

Aschmann, S. M., Shu, Y. H., Arey, J., and Atkinson, R.: Products of the gas-phase reactions of cis-3-hexen-1-ol with $\mathrm{OH}$ radicals and $\mathrm{O}_{3}^{-}$, Atmos. Environ., 31, 3551-3560, doi:10.1016/S13522310(97)00205-7, 1997.

Bahreini, R., Keywood, M. D., Ng, N. L., Varutbangkul, V., Gao, S., Flagan, R. C., Seinfeld, J. H., Worsnop, D. R., and Jimenez, J. L.: Measurements of secondary organic aerosol from oxidation of cycloalkenes, terpenes, and m-xylene using an Aerodyne aerosol mass spectrometer, Environ. Sci. Technol., 39, 56745688, doi:10.1021/Es048061a, 2005.

Bertschi, I. T. and Jaffe, D. A.: Long-range transport of ozone, carbon monoxide, and aerosols to the NE Pacific troposphere during the summer of 2003: Observations of smoke plumes from Asian boreal fires, J. Geophys. Res.-Atmos., 110, D05303 doi:10.1029/2004jd005135, 2005.

Brilli, F., Ruuskanen, T. M., Schnitzhofer, R., Muller, M., Breitenlechner, M., Bittner, V., Wohlfahrt, G., Loreto, F., and Hansel, A.: Detection of Plant Volatiles after Leaf Wounding and Darkening by Proton Transfer Reaction "Time-of-
Flight" Mass Spectrometry (PTR-TOF), PLOS One, 6, E20419, doi:10.1371/journal.pone.0020419, 2011.

Brilli, F., Hortnagl, L., Bamberger, I., Schnitzhofer, R., Ruuskanen, T. M., Hansel, A., Loreto, F., and Wohlfahrt, G.: Qualitative and Quantitative Characterization of Volatile Organic Compound Emissions from Cut Grass, Environ. Sci. Technol., 46, 38593865, doi:10.1021/Es204025y, 2012.

Cahill, T. M., Seaman, V. Y., Charles, M. J., Holzinger, R., and Goldstein, A. H.: Secondary organic aerosols formed from oxidation of biogenic volatile organic compounds in the Sierra Nevada Mountains of California, J. Geophys. Res.-Atmos., 111, D16312, doi:10.1029/2006jd007178, 2006.

Carlton, A. G., Wiedinmyer, C., and Kroll, J. H.: A review of Secondary Organic Aerosol (SOA) formation from isoprene, Atmos. Chem. Phys., 9, 4987-5005, doi:10.5194/acp-9-4987-2009, 2009.

Carlton, A. G., Pinder, R. W., Bhave, P. V., and Pouliot, G. A.: To What Extent Can Biogenic SOA be Controlled?, Environ. Sci. Technol., 44, 3376-3380, doi:10.1021/es903506b, 2010.

Carter, W. P. L., Cocker Iii, D. R., Fitz, D. R., Malkina, I. L., Bumiller, K., Sauer, C. G., Pisano, J. T., Bufalino, C., and Song, C.: A new environmental chamber for evaluation of gas-phase chemical mechanisms and secondary aerosol formation, Atmos. Environ., 39, 7768-7788, doi:10.1016/j.atmosenv.2005.08.040, 2005.

Clegg, S. L., Kleeman, M. J., Griffin, R. J., and Seinfeld, J. H.: Effects of uncertainties in the thermodynamic properties of aerosol components in an air quality model \&ndash; Part 2: Predictions of the vapour pressures of organic compounds, Atmos. Chem. Phys., 8, 1087-1103, doi:10.5194/acp-8-1087-2008, 2008.

Cocker, D. R., Flagan, R. C., and Seinfeld, J. H.: State-of-the-Art Chamber Facility for Studying Atmospheric Aerosol Chemistry, Environ. Sci. Technol., 35, 2594-2601, doi:10.1021/es0019169, 2001.

Dash, M. R., Balaganesh, M., and Rajakumar, B.: Rate coefficients for the gas-phase reaction of $\mathrm{OH}$ radical with $\alpha$-pinene: an experimental and computational study, Molec. Phys., 1-17, doi:10.1080/00268976.2013.840395, 2013.

de Gouw, J. A., Howard, C. J., Custer, T. G., and Fall, R.: Emissions of volatile organic compounds from cut grass and clover are enhanced during the drying process, Geophys. Res. Lett., 26, 811-814, 1999.

de Gouw, J. A., Middlebrook, A. M., Warneke, C., Goldan, P. D., Kuster, W. C., Roberts, J. M., Fehsenfeld, F. C., Worsnop, D. R., Canagaratna, M. R., Pszenny, A. A. P., Keene, W. C., Marchewka, M., Bertman, S. B., and Bates, T. S.: Budget of organic carbon in a polluted atmosphere: Results from the New England Air Quality Study in 2002, J. Geophys. Res. Atmos., 110, D16305, doi:10.1029/2004JD005623, 2005.

Diaz, E. A., Lemos, M., Coull, B., Long, M. S., Rohr, A. C., Ruiz, P., Gupta, T., Kang, C. M., and Godleski, J. J.: Toxicological Evaluation of Realistic Emission Source Aerosols (TERESA)-Power plant studies: assessment of breathing pattern, Inhal. Toxicol., 23, 42-59, doi:10.3109/08958378.2010.578169, 2011.

Drewnick, F., Dall'Osto, M., and Harrison, R. M.: Characterization of aerosol particles from grass mowing by joint deployment of ToF-AMS and ATOFMS instruments, Atmos. Environ., 42, 3006-3017, doi:10.1016/j.atmosenv.2007.12.047, 2008.

Emanuelsson, E. U., Hallquist, M., Kristensen, K., Glasius, M., Bohn, B., Fuchs, H., Kammer, B., Kiendler-Scharr, A., Nehr, S., 
Rubach, F., Tillmann, R., Wahner, A., Wu, H. C., and Mentel, T. F.: Formation of anthropogenic secondary organic aerosol (SOA) and its influence on biogenic SOA properties, Atmos. Chem. Phys., 13, 2837-2855, doi:10.5194/acp-13-2837-2013, 2013.

Fushimi, A., Wagai, R., Uchida, M., Hasegawa, S., Takahashi, K., Kondo, M., Hirabayashi, M., Morino, Y., Shibata, Y., Ohara, T., Kobayashi, S., and Tanabe, K.: Radiocarbon (C-14) Diurnal Variations in Fine Particles at Sites Downwind from Tokyo, Japan in Summer, Environ. Sci. Technol., 45, 6784-6792, doi:10.1021/Es201400p, 2011.

Glasius, M., la Cour, A., and Lohse, C.: Fossil and nonfossil carbon in fine particulate matter: A study of five European cities, J. Geophys. Res.-Atmos., 116, D11302, doi:10.1029/2011jd015646, 2011.

Grosjean, D., Grosjean, E., and Williams, E. L.: Rate Constants for the Gas-Phase Reactions of Ozone with Unsaturated Alcohols, Esters, and Carbonyls, Int. J. Chem. Kinet., 25, 783-794, doi:10.1002/kin.550250909, 1993.

Grosjean, E. and Grosjean, D.: Rate Constants for the Gas-Phase Reactions of Ozone with Unsaturated Aliphatic-Alcohols, Int. J. Chem. Kinet., 26, 1185-1191, doi:10.1002/kin.550261206, 1994.

Grosjean, E. and Grosjean, D.: The gas phase reaction of unsaturated oxygenates with ozone: Carbonyl products and comparison with the alkene-ozone reaction, J. Atmos. Chem., 27, 271-289, doi:10.1023/A:1005868119515, 1997.

Grosjean, E. and Grosjean, D.: The reaction of unsaturated aliphatic oxygenates with ozone, J. Atmos. Chem., 32, 205-232, doi:10.1023/A:1006122000643, 1999.

Guenther, A., Zimmerman, P., and Wildermuth, M.: Natural volatile organic compound emission rate estimates for U.S. woodland landscapes, Atmos. Environ., 28, 1197-1210, doi:10.1016/13522310(94)90297-6, 1994.

Guenther, A., Geron, C., Pierce, T., Lamb, B., Harley, P., and Fall, R.: Natural emissions of non-methane volatile organic compounds, carbon monoxide, and oxides of nitrogen from North America, Atmos. Environ., 34, 2205-2230, doi:10.1016/S13522310(99)00465-3, 2000

Guenther, A. B., Jiang, X., Heald, C. L., Sakulyanontvittaya, T., Duhl, T., Emmons, L. K., and Wang, X.: The Model of Emissions of Gases and Aerosols from Nature version 2.1 (MEGAN2.1): an extended and updated framework for modeling biogenic emissions, Geosci. Model. Dev., 5, 1471-1492, doi:10.5194/gmd-51471-2012, 2012.

Gulden, L. E., Yang, Z. L., and Niu, G. Y.: Interannual variation in biogenic emissions on a regional scale, J. Geophys. Res.-Atmos., 112, D14103, doi:10.1029/2006jd008231, 2007.

Hallquist, M., Wenger, J. C., Baltensperger, U., Rudich, Y., Simpson, D., Claeys, M., Dommen, J., Donahue, N. M., George, C., Goldstein, A. H., Hamilton, J. F., Herrmann, H., Hoffmann, T., Iinuma, Y., Jang, M., Jenkin, M. E., Jimenez, J. L., KiendlerScharr, A., Maenhaut, W., McFiggans, G., Mentel, T. F., Monod, A., Prevot, A. S. H., Seinfeld, J. H., Surratt, J. D., Szmigielski, R., and Wildt, J.: The formation, properties and impact of secondary organic aerosol: current and emerging issues, Atmos. Chem. Phys., 9, 5155-5236, doi:10.5194/acp-9-5155-2009, 2009.

Hamilton, J. F., Lewis, A. C., Carey, T. J., and Wenger, J. C.: Characterization of polar compounds and oligomers in secondary organic aerosol using liquid chromatography coupled to mass spec- trometry, Anal. Chem., 80, 474-480, doi:10.1021/Ac701852t, 2008.

Hamilton, J. F., Lewis, A. C., Carey, T. J., Wenger, J. C., Garcia, E. B. I., and Munoz, A.: Reactive oxidation products promote secondary organic aerosol formation from green leaf volatiles, Atmos. Chem. Phys., 9, 3815-3823, doi:10.5194/acp-9-3815-2009, 2009.

Hartikainen, K., Riikonen, J., Nerg, A. M., Kivimaenpaa, M., Ahonen, V., Tervahauta, A., Karenlampi, S., Maenpaa, M., Rousi, M., Kontunen-Soppela, S., Oksanen, E., and Holopainen, T.: Impact of elevated temperature and ozone on the emission of volatile organic compounds and gas exchange of silver birch (Betula pendula Roth), Environ. Exp. Bot., 84, 33-43, doi:10.1016/j.envexpbot.2012.04.014, 2012.

Hatanaka, A.: The Biogeneration of Green Odor by Green Leaves, Phytochemistry, 34, 1201-1218, doi:10.1016/00319422(91)80003-J, 1993.

Heiden, A. C., Kobel, K., Langebartels, C., Schuh-Thomas, G., and Wildt, J.: Emissions of oxygenated volatile organic compounds from plants - part I: Emissions from lipoxygenase activity, J. Atmos. Chem., 45, 143-172, doi:10.1023/A:1024069605420, 2003.

Helmig, D.: Ozone removal techniques in the sampling of atmospheric volatile organic trace gases, Atmos. Environ., 31, 36353651, 1997.

Hildebrandt, L., Henry, K. M., Kroll, J. H., Worsnop, D. R., Pandis, S. N., and Donahue, N. M.: Evaluating the Mixing of Organic Aerosol Components Using High-Resolution Aerosol Mass Spectrometry, Environ. Sci. Technol., 45, 6329-6335, doi:10.1021/Es200825g, 2011.

Hoyle, C. R., Boy, M., Donahue, N. M., Fry, J. L., Glasius, M., Guenther, A., Hallar, A. G., Hartz, K. H., Petters, M. D., Petaja, T., Rosenoern, T., and Sullivan, A. P.: A review of the anthropogenic influence on biogenic secondary organic aerosol, Atmos. Chem. Phys., 11, 321-343, doi:10.5194/acp-11-321-2011, 2011.

Keywood, M. D., Varutbangkul, V., Bahreini, R., Flagan, R. C., and Seinfeld, J. H.: Secondary organic aerosol formation from the ozonolysis of cycloalkenes and related compounds, Environ. Sci. Technol., 38, 4157-4164, doi:10.1021/Es.035363o, 2004.

Jardine, K., Barron-Gafford, G. A., Norman, J. P., Abrell, L., Monson, R. K., Meyers, K. T., Pavao-Zuckerman, M., Dontsova, K., Kleist, E., Werner, C., and Huxman, T. E.: Green leaf volatiles and oxygenated metabolite emission bursts from mesquite branches following light-dark transitions, Photosynth. Res., 113, 321-333, doi:10.1007/s11120-012-9746-5, 2012.

Joutsensaari, J., Loivamaki, M., Vuorinen, T., Miettinen, P., Nerg, A. M., Holopainen, J. K., and Laaksonen, A.: Nanoparticle formation by ozonolysis of inducible plant volatiles, Atmos. Chem. Phys., 5, 1489-1495, 2005,

http://www.atmos-chem-phys.net/5/1489/2005/.

Kanakidou, M., Seinfeld, J. H., Pandis, S. N., Dentener, F. J., Facchini, M. C., Van Dingenen, R., Ervens, B., Nenes, A., Nielson, C. J., Swietlicki, E., Putaud, J. P., Balkanski, Y., Fuzzi, S., Horth, J., Moortgat, G. K., Winterhalter, R., Myhre, C. E. L., Tsigaridis, K., Vignati, E., Stephanou, E. G., and Wilson, J.: Organic aerosol and global climate modelling: a review, Atmos. Chem. Phys., 5, 1053-1123, doi:10.5194/acp-5-1053-2005, 2005. 
Karl, T., Fall, R., Jordan, A., and Lindinger, W.: On-line analysis of reactive VOCs from urban lawn mowing, Environ. Sci. Technol., 35, 2926-2931, doi:10.1021/Es010637y, 2001.

Karl, T., Harren, F., Warneke, C., de Gouw, J., Grayless, C., and Fall, R.: Senescing grass crops as regional sources of reactive volatile organic compounds, J. Geophys. Res.-Atmos., 110, D15302, doi:10.1029/2005jd005777, 2005.

Kiendler-Scharr, A., Wildt, J., Maso, M. D., Hohaus, T., Kleist, E., Mentel, T. F., Tillmann, R., Uerlings, R., Schurr, U., and Wahner, A.: New particle formation in forests inhibited by isoprene emissions, Nature, 461, 381-384, 2009.

Kirstine, W., Galbally, I., Ye, Y. R., and Hooper, M.: Emissions of volatile organic compounds (primarily oxygenated species) from pasture, J. Geophys. Res.-Atmos., 103, 10605-10619, doi:10.1029/97JD03753, 1998.

Kirstine, W., Galbally, I., Hooper, M.: Air Pollution and the Smell of Cut Grass, 16th International Clean Air Conference, Christchurch, New Zealand, 2002.

Kirstine, W. V. and Galbally, I. E.: A simple model for estimating emissions of volatile organic compounds from grass and cut grass in urban airsheds and its application to two Australian cities, J. Air Waste Manage., 54, 1299-1311, 2004.

Kivimäenpää, M., Riikonen, J., Ahonen, V., Tervahauta, A., and Holopainen, T.: Sensitivity of Norway spruce physiology and terpenoid emission dynamics to elevated ozone and elevated temperature under open-field exposure, Environ. Exp. Bot., 90, 3242, doi:10.1016/j.envexpbot.2012.11.004, 2013.

Kroll, J. H. and Seinfeld, J. H.: Chemistry of secondary organic aerosol: Formation and evolution of low-volatility organics in the atmosphere, Atmos. Environ., 42, 3593-3624, doi:10.1016/j.atmosenv.2008.01.003, 2008.

Lee, S. H., Kim, S. W., Trainer, M., Frost, G. J., McKeen, S. A., Cooper, O. R., Flocke, F., Holloway, J. S., Neuman, J. A., Ryerson, T., Senff, C. J., Swanson, A. L., and Thompson, A. M.: Modeling ozone plumes observed downwind of New York City over the North Atlantic Ocean during the ICARTT field campaign, Atmos. Chem. Phys., 11, 7375-7397, doi:10.5194/acp-11-73752011, 2011.

Lefohn, A. S., Shadwick, D., and Oltmans, S. J.: Characterizing changes in surface ozone levels in metropolitan and rural areas in the United States for 1980-2008 and 1994-2008, Atmos. Environ., 44, 5199-5210, doi:10.1016/j.atmosenv.2010.08.049, 2010.

Li, J., Sun, Y., Cao, H., Han, D., and He, M.: Mechanisms and kinetics of the ozonolysis reaction of cis-3-hexenyl acetate and trans-2-hexenyl acetate in atmosphere: a theoretical study, Struct. Chem., 1-13, doi:10.1007/s11224-013-0226-0, 2013.

Mao, H. T., Talbot, R., Troop, D., Johnson, R., Businger, S., and Thompson, A. M.: Smart balloon observations over the North Atlantic: O-3 data analysis and modeling, J. Geophys. Res.-Atmos., 111, D23S56 doi:10.1029/2005JD006507, 2006.

Mentel, T. F., Kleist, E., Andres, S., Maso, M. D., Hohaus1, T., Kiendler-Scharr, A., Y. Rudich4, M. S., R. Tillmann1, R. U., Wahner, A., and Wildt, J.: Secondary aerosol formation from stress-induced biogenic emissions and possible climate feedbacks, Atmos. Chem. Phys., 13, 8755-8770, doi:10.5194/acp13-8755-2013, 2013.

Miller-Schulze, J. P., Shafer, M. M., Schauer, J. J., Solomon, P. A., Lantz, J., Artamonova, M., Chen, B., Imashev, S., Sverdlik, L., Carmichael, G. R., and Deminter, J. T.: Char- acteristics of fine particle carbonaceous aerosol at two remote sites in Central Asia, Atmos. Environ., 45, 6955-6964, doi:10.1016/j.atmosenv.2011.09.026, 2011.

Miresmailli, S., Zeri, M., Zangerl, A. R., Bernacchi, C. J., Berenbaum, M. R., and DeLucia, E. H.: Impacts of herbaceous bioenergy crops on atmospheric volatile organic composition and potential consequences for global climate change, Gcb Bioenergy, 5, 375-383, doi:10.1111/j.1757-1707.2012.01189.x, 2013.

Moller, B., Rarey, J., and Ramjugernath, D.: Estimation of the vapour pressure of non-electrolyte organic compounds via group contributions and group interactions, J. Mol. Liq., 143, 52-63, doi:10.1016/j.molliq.2008.04.020, 2008.

Myrdal, P. B. and Yalkowsky, S. H.: Estimating pure component vapor pressures of complex organic molecules, Ind. Eng. Chem. Res., 36, 2494-2499, doi:10.1021/Ie9502421, 1997.

Nannoolal, Y., Rarey, J., Ramjugernath, D., and Cordes, W.: Estimation of pure component properties Part 1. Estimation of the normal boiling point of non-electrolyte organic compounds via group contributions and group interactions, Fluid Phase Equilibr., 226, 45-63, doi:10.1016/j.fluid.2004.09.001, 2004.

Nannoolal, Y., Rarey, J., and Ramjugernath, D.: Estimation of pure component properties - Part 3. Estimation of the vapor pressure of non-electrolyte organic compounds via group contributions and group interactions, Fluid Phase Equilibr., 269, 117 133, doi:10.1016/j.fluid.2008.04.020, 2008.

Nemitz, E., Dorsey, J. R., Flynn, M. J., Gallagher, M. W., Hensen, A., Erisman, J. W., Owen, S. M., Dammgen, U., and Sutton, M. A.: Aerosol fluxes and particle growth above managed grassland, Biogeosciences, 6, 1627-1645, doi:10.5194/bg-6-16272009, 2009.

O’Dwyer, M. A., Carey, T. J., Healy, R. M., Wenger, J. C., PicquetVarrault, B., and Doussin, J. F.: The Gas-phase Ozonolysis of 1-Penten-3-ol, (Z)-2-Penten-1-ol and 1-Penten-3-one: Kinetics, Products and Secondary Organic Aerosol Formation, Z. Phys. Chem., 224, 1059-1080, doi:10.1524/zpch.2010.6141, 2010.

Odum, J. R., Hoffmann, T., Bowman, F., Collins, D., Flagan, R. C., and Seinfeld, J. H.: Gas/Particle partitioning and secondary organic aerosol yields, Environ. Sci. Technol., 30, 2580-2585, 1996.

Olofsson, M., Ek-Olausson, B., Ljungstrom, E., and Langer, S.: Flux of organic compounds from grass measured by relaxed eddy accumulation technique, J. Environ. Monitor., 5, 963-970, doi:10.1039/B303329e, 2003.

Orlando, J. J., Tyndall, G. S., and Ceazan, N.: Rate coefficients and product yields from reaction of $\mathrm{OH}$ with 1-penten-3-ol, (Z)-2-penten-1-ol, and allyl alcohol (2-propen-1-ol), Journal of Physical Chemistry A, 105, 3564-3569, doi:10.1021/Jp0041712, 2001.

Ormeno, E., Gentner, D. R., Fares, S., Karlik, J., Park, J. H., and Goldstein, A. H.: Sesquiterpenoid Emissions from Agricultural Crops: Correlations to Monoterpenoid Emissions and Leaf Terpene Content, Environ. Sci. Technol., 44, 3758-3764, doi:10.1021/Es903674m, 2010.

Papagni, C., Arey, J., and Atkinson, R.: Rate constants for the gasphase reactions of $\mathrm{OH}$ radicals with a series of unsaturated alcohols, Int. J. Chem. Kinet., 33, 142-147, doi:10.1002/10974601(200102)33:2<142::Aid-Kin1007>3.0.Co; 2-F, 2001.

Pinto, D. M., Nerg, A. M., and Holopainen, J. K.: The role of ozonereactive compounds, terpenes, and green leaf volatiles (GLVs), 
in the orientation of Cotesia plutellae, J. Chem. Ecol., 33, 22182228, doi:10.1007/s10886-007-9376-0, 2007.

Presto, A. A., Huff Hartz, K. E., and Donahue, N. M.: Secondary Organic Aerosol Production from Terpene Ozonolysis. 1. Effect of UV Radiation, Environ. Sci. Technol., 39, 7036-7045, doi:10.1021/es050174m, 2005.

Reisen, F., Aschmann, S. M., Atkinson, R., and Arey, J.: Hydroxyaldehyde products from hydroxyl radical reactions of Z-3-hexen-1-ol and 2-methyl-3-buten-2-ol quantified hy SPME and API-MS, Environ. Sci. Technol., 37, 4664-4671, doi:10.1021/Es034142f, 2003.

Robbins, P. and Birkenholtz, T.: Turfgrass revolution: measuring the expansion of the American lawn, Land Use Policy, 20, 181-194, doi:10.1016/S0264-8377(03)00006-1, 2003.

Shilling, J. E., Zaveri, R. A., Fast, J. D., Kleinman, L., Alexander, M. L., Canagaratna, M. R., Fortner, E., Hubbe, J. M., Jayne, J. T., Sedlacek, A., Setyan, A., Springston, S., Worsnop, D. R., and Zhang, Q.: Enhanced SOA formation from mixed anthropogenic and biogenic emissions during the CARES campaign, Atmos. Chem. Phys., 13, 2091-2113, doi:10.5194/acp-13-20912013, 2013.

Solomon, S. D., Qin, M. M., Chen, Z., Marquis, M., Averyt, K. B., Tignor, M., and Miller, H. L. e.: Contribution of Working Group I to the Fourth Assessment Report of the Intergovernmental Panel on Climate Change, 2007, Cambridge University Press,, Cambridge, UK and New York, NY, USA., 2007.

Spracklen, D. V., Jimenez, J. L., Carslaw, K. S., Worsnop, D. R., Evans, M. J., Mann, G. W., Zhang, Q., Canagaratna, M. R., Allan, J., Coe, H., McFiggans, G., Rap, A., and Forster, P.: Aerosol mass spectrometer constraint on the global secondary organic aerosol budget, Atmos. Chem. Phys., 11, 12109-12136, doi:10.5194/acp-11-12109-2011, 2011.

Starn, T. K., Shepson, P. B., Bertman, S. B., Riemer, D. D., Zika, R. G., and Olszyna, K.: Nighttime isoprene chemistry at an urbanimpacted forest site, J. Geophys. Res. Atmos., 103, 2243722447, doi:10.1029/98jd01201, 1998.

Stein, S. E. and Brown, R. L.: Estimation of Normal Boiling Points from Group Contributions, J. Chem. Inf. Comp. Sci., 34, 581587, doi:10.1021/Ci00019a016, 1994.

Steinbrecher, R., Klauer, M., Hauff, K., Stockwell, W. R., Jaeschke, W., Dietrich, T., and Herbert, F.: Biogenic and anthropogenic fluxes of non-methane hydrocarbons over an urban-impacted forest, Frankfurter Stadtwald, Germany, Atmos. Environ., 34, 37793788, doi:10.1016/S1352-2310(99)00518-X, 2000.
Stevenson, N.: Encouraging Environmentally Responsible Lawn Care Behavior in New England: Utilizing Social Science to Develop Successful Outreach and Education, M. S., Environmental Science and Policy, Plymouth State University, 172 pp., 2010.

Uchiyama, S., Inaba, Y., and Kunugita, N.: Ozone removal in the collection of carbonyl compounds in air, Journal of chromatography. A, 1229, 293-297, doi:10.1016/j.chroma.2012.01.062, 2012.

US Environmental Protection Agency, Trends in Ozone Adjusted for Weather Conditions: http://www.epa.gov/airtrends/weather. html (last access: 13 May 2013), 2013.

Wang, T., Ding, A. J., Gao, J., and Wu, W. S.: Strong ozone production in urban plumes from Beijing, China, Geophys. Res. Lett., 33, L21806, doi:10.1029/2006g1027689, 2006.

Watkins, E., Gianfagna, T. J., Sun, R. Q., and Meyer, W. A.: Volatile compounds of tufted hairgrass, Crop. Sci., 46, 25752580, doi:10.2135/cropsci2006.02.0094, 2006.

Woodbury, P. B., Laurence, J. A., and Hudler, G. W.: Chronic Ozone Exposure Increases the Susceptibility of Hybrid Populus to Disease Caused by Septoria-Musiva, Environ. Pollut., 86, 109-114, doi:10.1016/0269-7491(94)90012-4, 1994.

Wu, J. D. and Bauer, M. E.: Estimating Net Primary Production of Turfgrass in an Urban-Suburban Landscape with QuickBird Imagery, Remote Sens.-Basel, 4, 849-866, doi:10.3390/Rs4040849, 2012.

Wu, S., Lu, Z. F., Hao, J. M., Zhao, Z., Li, J. H., Hideto, T., Hiroaki, M., and Akio, Y.: Construction and characterization of an atmospheric simulation smog chamber, Adv. Atmos. Sci., 24, 250258, doi:10.1007/s00376-007-0250-3, 2007.

Zheng, D. L., Ducey, M. J., and Heath, L. S.: Assessing net carbon sequestration on urban and community forests of northern New England, USA, Urban for Urban Gree, 12, 61-68, doi:10.1016/j.ufug.2012.10.003, 2013.

Yee, L. D., Craven, J. S., Loza, C. L., Schilling, K. A., Ng, N. L., Canagaratna, M. R., Ziemann, P. J., Flagan, R. C., and Seinfeld, J. H.: Effect of chemical structure on secondary organic aerosol formation from C12 alkanes, Atmos. Chem. Phys., 13, 1112111140, doi:10.5194/acp-13-11121-2013, 2013. 